\title{
'EXPERIENCING FELLOWSHIP WITH GOD' ACCORDING TO 1 JOHN 1:5-2:28: DEALING WITH THE CHANGE IN SOCIAL BEHAVIOUR
}

\author{
D.G. Van der Merwe \\ (University of South Africa)
}

\begin{abstract}
From the First Epistle of John it is evident that the constitution of

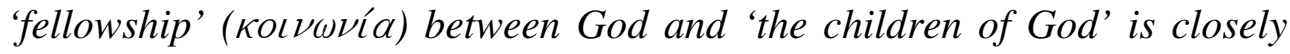
related with a lifestyle related to the three attributes of God recited in the

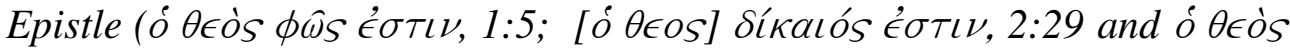

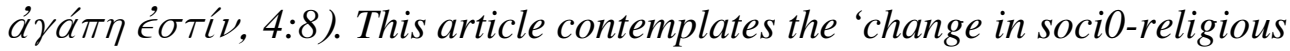
behaviour' relating to the attribute of 'God is Light' as stated in 1:5.

Following the emphatic statement in 1:5, the Elder discusses some conditions for having fellowship with God (1:6-2:28). Grounded in the nature of God as light (1:5), these conditions are contrasted with the conduct of the author's opponents and are implemented through the Holy Spirit. It comprises: (1) the renounce of sin; (2) the exhortation to obedience; (3) the exhortation to reject worldliness; and (4) the exhortation to mutual abidance.
\end{abstract}

\section{Introduction}

Interest in spirituality is a global phenomenon. ${ }^{1}$ It occurs, as a matter of fact, in most religions. In Christianity, the interest in spirituality is a growing tendency and one of the major reasons for the phenomenal growth in the Pentecostal and Charismatic church traditions. ${ }^{2}$ Although different kinds of spiritualities can be defined, the approach in this article will focus, from a Christian perspective, on the 'experience of fellowship with God' as depicted in 1 John 1:5-2:28. This is due to the four occurrences of the noun

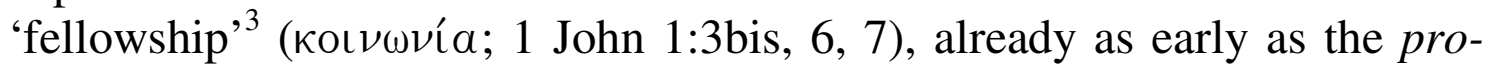
oemium (1:3bis) and at the beginning $(1: 6,7)$ of the first section $(1: 5-2: 28)$ of the first epistle of John. The noun 'fellowship' is used by the Elder ${ }^{4}$ to describe this close relationship. It is a richly significant theological term based on the adjective meaning 'common' (Kolvós), denoting the active participation or sharing in what one has in common with others (Haas, De Jonge, Swellengrebel 1972:27). As used in the context of 1 John it can probably have a multiplicity of meanings, which can refer to 'live in communion with,' 'be in a right relationship with,' 'be part of the family of God,' or 'share the same life' (cf. Johnson 1993:29; Haas, De Jonge, Swellengrebel 1972:27). ${ }^{5}$ The nature of what is mutually shared moulds the character of the group. 
To encourage and advance this Christian fellowship in the Johannine community, the Elder emphasizes its vital vertical aspect: 'and indeed our fellowship is with the Father and with his Son Jesus Christ' (1:3). Fellowship with God then is dependent on the fellowship with one another and contrariwise (cf. Painter 2002:128; also Rusam 1993:182) ${ }^{6}$. Each of these two aspects reflects, influences and constitutes the other. By using the noun

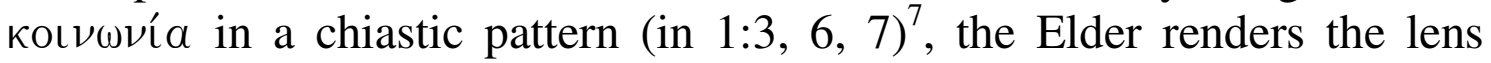
through which 1 John has to be read and to be understood.

Therefore, the approach of this article is not a matter of solving a formulated and defined problem, but rather to make a new contribution in investigating the concept of 'having or experiencing fellowship with God'; to formulate briefly what it comprises and to concentrate especially how it can be accomplished through a change in socio-religious behaviour according to 1 John 1:5-2:28. A second contribution is to investigate this 'fellowship with God' and 'change in behaviour' from the perception of the familia Dei which constitutes for the Elder his symbolic narrative in which he describes how the behaviour of his adherents must feature and their fellowship be experienced. A third contribution will be to interpret the two above mentioned statements from, and relate it to, the metaphorical indication of God as 'Light' (1:5). In order to achieve this, methodologically, a socio-rhetorical ${ }^{8}$ investigation of 1 John 1:5-2:28 will be conducted.

Therefore, inner-textually, the selected text (1:5-2:28) will be divided into sensible sub-sections which will be investigated individually. Such an investigation will be conducted from the Elder's symbolic narrative (the ideological texture in the epistle), the familia Dei, and is presented in this epistle in contrast to the conduct of the Elder's opponents (the socioreligious texture in the epistle). In this symbolic narrative the focus contemplates on the allusion to 'God is Light'" as stated in 1:5a and its implications for the children of God to walk in the light as a prerequisite for the experience of fellowship (sacred texture). ${ }^{10}$ In this article it will be pointed out that such an experience demands a change in socio-religious behaviour which the Elder spells out in terms of four ethic-and-theologically combined conditions.

\section{Experiencing fellowship in the familia dei}

Already in chapter 1 the Elder portrays this Christian life of fellowship ${ }^{11}$ in the Johannine community as existence in a family (Van der Merwe 2005: 
443f; also Rusam 1993:105ff; Van der Watt 1999:494ff; cf. also Dodd 1953:65ff), where God is the Father (3:1,) in the family (familia Dei), Jesus

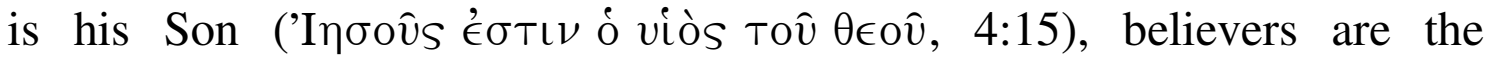
children of God ( $(\epsilon \in \kappa \nu \alpha \theta \in \mathrm{v}, 3: 1$ ) and the Holy Spirit is the Spirit of God (Tò $\pi \nu \in \hat{v} \mu \alpha$ Tôे $\theta \in o \hat{v}, 4: 2 \mathrm{f}$ ), which constitutes the presence of God and executes his involvement in the familia Dei.

Such family life has to be understood in the light of first-century Mediterranean group life. It is generally accepted by scholars who work socialscientifically that first-century Mediterranean people were not individualistic, but had a 'dyadic' or group-oriented personality. For people of that time and place, the basic, most elementary unit of social analysis, is not the individual person but the dyad, a person in relation with and connected to at least one other social unit, in particular, the family (MalinaNeyrey 1993:72-3; Esler 2002:151). Wilson (1996:2; also cf. Kloppenborg 1996:16-7) takes it even further by noting that all the associations of the Graeco-Roman world (synagogues, households, schools of philosophy, collegiums, guilds, mystery cults, etc.) were 'voluntary associations'. Many associations were organized in a manner that both reflected and reinforced the existing social order, for example family or household cults (Wilson 1996:2). Kloppenborg (1996:16) reinforces such an idea by asserting that 'voluntary associations represented a cultural institution integral to Hellenistic and Roman society where they played a significant role in mediating various kinds of social exchange'.

Therefore, it would seem most appropriate, according to Kloppenborg (1996:26), to distinguish voluntary associations on the basis of their respective membership bases rather than on the basis of their ostensible functions. For him, three groups could be distinguished: (1) those associated with a household; (2) those formed around a common trade (and civic locale), and (3) those formed around the cult of a deity. In the case the Johannine community, as it is for any Christian group, all the members are associated around the person and following of Jesus, acknowledged not only as God, but also the patron of the association.

Harland (2003:179), influenced by Judge, reflects more specifically on the position of Christianity in its formative years in the sense that Christianity did not live in a vacuum, isolated from the rest of the Graeco-Roman society; rather, once established in the polis of Roman Empire, the Christian group 'belongs inevitably, as a social phenomenon, to the Hellenistic republics [i.e., poleis]. Its thinking and behaviour naturally reflect the 
social institutions of these states'. ${ }^{12}$ But despite all the similarities shared by these groups or associations, there were differences - in ideology, organization, membership, and purpose - among them (Wilson 1996:9). Since the dyadic individual is symptomatic and representative of some group, the responsibility for morality and deviance is not on the individual alone, but on the social body in which the individual is embedded (MalinaNeyrey 1993:76). Therefore, these people defined themselves exclusively in terms of these groups or associations in which they are embedded; their total self-awareness emphatically depends upon this group embeddedness.

Societies featuring dyadic personality provide their members with individual identities that are clearly defined which are, in the case of the Johannine community, legitimated by reference to their fellowship with God. This implies that certain values will prevail and certain virtues prescribed and certain vices proscribed. The result is a form of paraenesis appeal is made to what is held in common and agreed to in terms of maxims, or commonly shared symbols (Malina-Neyrey 1993:79). Central to their socio-religious identity are group norms (Brown 2000:42-8). A norm in this context would have been a scale of values which defines a variety of acceptable and unacceptable attitudes and behaviour by members of the group. Norms co-ordinate and regulate behaviour and cover issues such as ideologies, traditions, and mores. They assist members to act appropriately in new and ambiguous situations (Esler 2000:160; Brown 2000:251). In the case of the Johannine community the Elder explicates some norms, which relate to their identity and which distinguish them from other groups, to which they ought to live. Obedience to these norms constitutes the mutual and corporate fellowship. This he defines in terms of family life which tended to be the main group in these group-oriented Mediterranean societies.

This spiritual family transcends, existentially and ethically, the physical family to which a person belongs. This implies that that person exists in a different mode of existence on earth - already possessing eternal life. Supreme loyalty is owed to this spiritual family. When a person accepts this new way of life, new rules and new values replace previous traditions, rules and values. Birth from God $(5: 1,18)$ is essential, for the child of God has to take on the same life as the Father, which must be evident in the conduct of the family. Christian Family life then implies specific ethical and religious conduct that relate to the attributes of God (o $\theta \in \hat{o} s$ $\phi \hat{\omega} S$

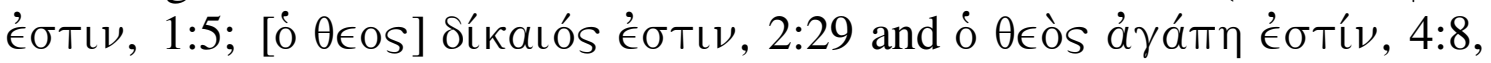
16) who is depicted by the Elder as the head (Father) of this family, as 
spelled out in 1 John.

In order to comprehend the necessity and content of this change in socioreligious behaviour it requires an understanding of the depiction of God in 1:5a. Here the Elder proclaims that 'God is light, and in Him there is no darkness at all.' This positive proclamation that 'God is light,' in the protasis of the verse, is a metaphorical statement of God's nature in relation to his children (cf. Johnson 1993:28; also Bultmann 1973:16; Strecker 1996:25). ${ }^{13}$

Due to the qualitative differences between the earthly and the divine, the divine can only be described in earthly terms with reference to earthly associations and categories. Hence, if the Elder wants to speak about God he does it by means of metaphors. Although human concepts are used, reference is made to divine reality. Thus when the Elder refers to God as 'light,' this surface ${ }^{14}$ metaphor does not create the reality of light, but aims to describe that reality (Van der Watt 2000:23). ${ }^{15}$ Ordinary words only function analogically ${ }^{16}$ and do not fully cover all the aspects of the heavenly reality. This implies that metaphoric allows for gradual differences within the phenomena which are described as metaphors (Van der Watt 2000:24).

In order to understand the metaphor in 1:5a, cognizance can be taken of what Gräbe says about metaphors. She (1992:288) points out that normally, uniform explanations are given to lexicalized expressions. But actually, first impressions are important and generally known associations should be given preference. Also the context is of major importance in this regard. Hence, according to the first impression of light, from the immediate literary context and symbolic narrative (familia Dei), it can be deduced that the metaphor used in 1:5 reflects God's enlightenment ${ }^{17}$ (Hiebert 1988:331; cf. also Krimmer 1989:26) and holiness. Hiebert (1988:331) points out that just as light reveals and purifies, so, by His very nature, God illuminates and sanctifies those who come to Him. Whatever symbolic associations this metaphoric designation may include, it definitely involves an ethical perceptive (Bruce 1970:41; Haas, De Jonge, Swellengrebel 1972:32) as spelled out in 1:6-2:17 and religious and confessional perceptives as spelled out in 2:18-28 which complement the ethical perceptive.

The Elder reinforces the concept of the preceding positively-stated clause

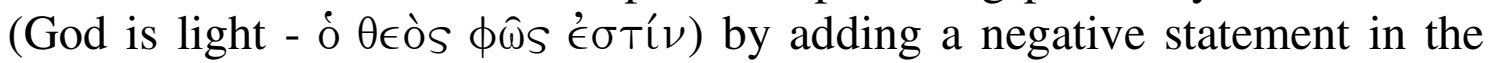

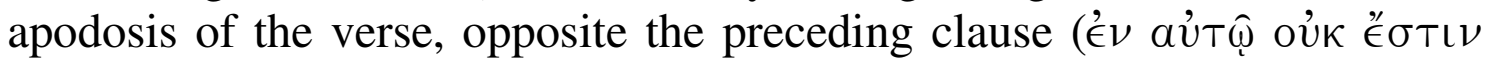




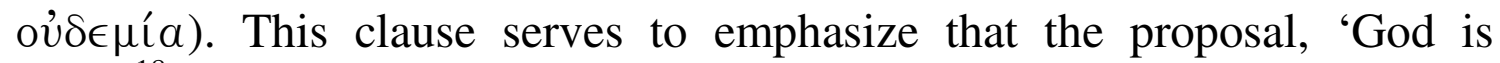
light, ${ }^{18}$ is absolute, without any exception. In the Greek text two negative

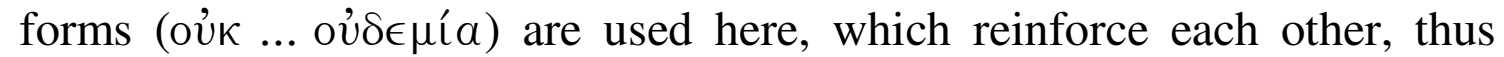
expressing an emphatic negation (Haas, De Jonge, Swellengrebel 1972:32). For the Elder then, 'darkness' ( $\sigma \kappa о \tau i ́ a)$ is not merely the absence of light; metaphorically it has a secular-moral quality reflecting the absence of salvation and of God, standing in direct antithesis to all that characterizes God as 'light.' For him 'light' and 'darkness' represent two separate and distinct realms in opposition to each other. God and his children constitute the one realm; Satan and his followers (the world) the other (cf. Hiebert 1988:331f).

The statement 'God is light' thus carries with it an inevitable sacred-moral challenge: his children must walk ( $\pi \in \rho\llcorner\pi a \tau \epsilon \hat{\imath} \nu$ ) in the light due to his (God's) nature; 'ought to walk just as he [Jesus] walked.' To live in the light keeps the children of God in the familia Dei in fellowship with the Father, his Son, the Spirit and fellow brothers (and sisters, 4:13-21). ${ }^{19}$ The experience of such fellowship will now be discussed.

\section{3. 'Fellowship with God' comprises}

While it is faith in the apostolic proclamation concerning Jesus that brings the adherents of the Elder into Christian fellowship, if the sense of 'fellowship' is common participation in something, then that something in this context would appear to be eternal life. 'Our fellowship is with the Father and with his Son' $(1: 3 b)$, and that which is shared is 'the eternal life which was with the Father and has appeared to us' $(1: 2)$ in the person of the Son. The immediate context then refers to eternal life as the medium and sphere of the experience of this fellowship. Hence, the adherents of the Elder share in the life of God. But this fellowship, according to the context of 1:5-2:28, can be broken down in terms of: to experience the love of God (2:5); to experience the forgiveness of God (1:9); to know God (2:3; also cf. 2:20); to know the truth (2:21); and to experience the abidance of God, the Son and the Spirit $(2: 14,24,27$; cf. $2: 28)$ in the believer.

\section{4. 'Fellowship with God' demands a change in socio-religious beha- viour}

The Elder addresses his adherents as people who have already 'been born of God' or alternatively spoken 'came to faith in Christ'. Therefore, they, as God's children, have to behave in accordance with specific sacred- 
ethical conduct (rules and values) of the familia Dei into which they are born. This has been determined by God, their Father. Therefore, the Elder insists upon a correspondence between internal state (to be 'in Him', 1:5) and external behaviour (to 'abide in Him', 1:6). The á $\gamma \gamma \in \lambda$ ía correlates to ÉVTO入̀̀ (Kenney 2000b:21). Through walking in the light, the children of God, individually and corporately, will experience the presence, reality and the involvement of God in their lives.

The conditions, spelled out in 1:6-2:28, to constitute communion between God and believers and which complement one another, will now be discussed.

\subsection{The first condition for having fellowship with God: Renounce sin $(1: 6-2: 2)$}

In the sub-section 1:6-2:2, the Elder describes how $\sin ^{20}$ hampers fellowship in the familia Dei and alternatively provides the corrective (cf. Culpepper 1998:257). Three tests are laid down by him in the form of false claims introduced by the conditional clause 'if we say' ('€́̀ $\nu \in l \pi \omega \mu \in \nu$ ǑTl, $6 \mathrm{a}, 8 \mathrm{a}, 10 \mathrm{a})$ in the protasis of these verses. Each of these three tests consists of two parts: the first positive and the second negative (cf. Bruce 1970:42). ${ }^{21}$ The first part contains a claim, the second a condemnation with a negative consequence. In the first two tests the correctives (introduced by a conditional particle $\epsilon^{\epsilon} \alpha े \nu$ ) are supplied in verses 7 and 9. In the third test (also éà $\nu, 2: 1 \mathrm{f}$ ) the Elder advances to a higher level. Instead of supplying another corrective, he moves over to the provision made to address the problem of $\sin ^{22}$

The following is a tabled synopsis of the structure of 1:6-2:2.

\begin{tabular}{|c|c|c|c|c|c|}
\hline & CLAIM & CONDEM- & CONSE- & \multicolumn{2}{|c|}{ CORRECTIVE/PROVISION } \\
\hline $1: 6-7$ & 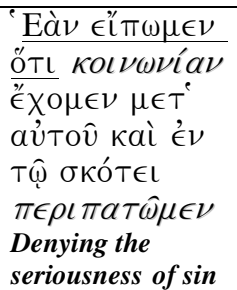 & $\psi \in v \delta o ́ \mu \epsilon \theta a$ & 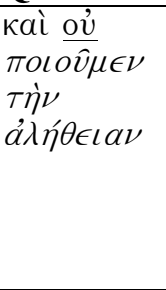 & 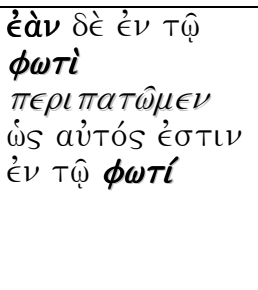 & 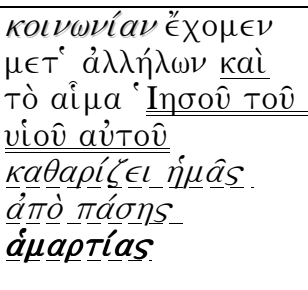 \\
\hline $1: 8-9$ & 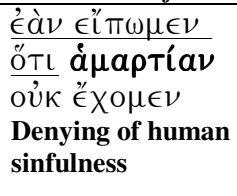 & 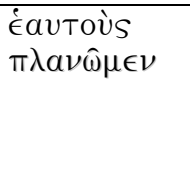 & 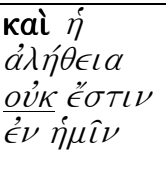 & $\begin{array}{l}\dot{\epsilon} \grave{\alpha} \nu \text { ó } \mu \mathrm{o} \lambda \mathrm{\gamma} \gamma \hat{\omega}- \\
\mu \in \nu \text { Tàs å } \mu \alpha \rho- \\
\text { Tías } \dot{\eta} \mu \hat{\omega} \nu\end{array}$ & 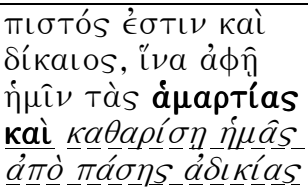 \\
\hline $1: 10-$ & $\hat{\epsilon} \dot{\alpha} \nu \in \epsilon^{\prime} \pi \omega \mu \epsilon \nu$ & $\psi \in \hat{v} \sigma \tau \eta \nu$ & кaì $\delta$ & ... Tav̂Ta $\gamma \rho a ́ \phi \omega$ & 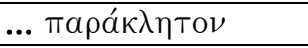 \\
\hline
\end{tabular}




\begin{tabular}{|c|c|c|c|c|c|}
\hline $2: 2$ & 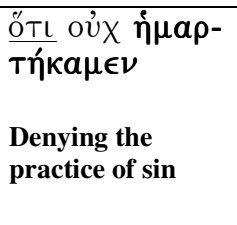 & $\begin{array}{l}\text { TOLOÛ } \mu \in \nu \\
\alpha \dot{v} \tau \dot{\nu} \nu\end{array}$ & 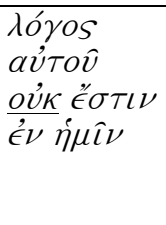 & 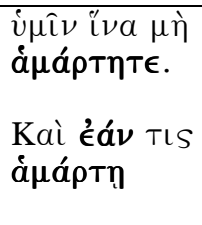 & 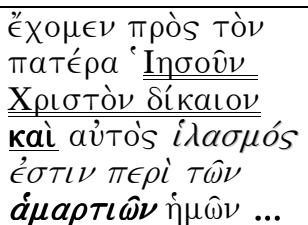 \\
\hline
\end{tabular}

In this section the Elder starts the protasis of verses 6,8 and 10 with

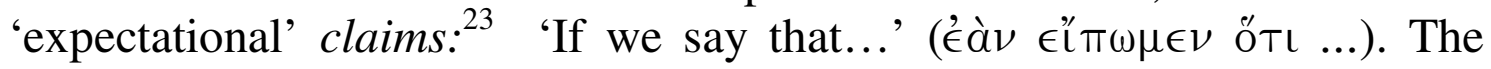

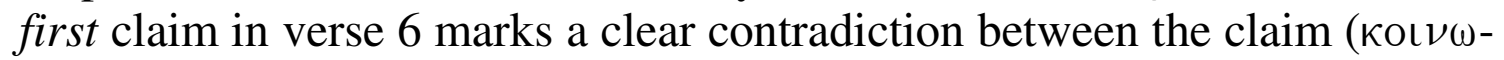

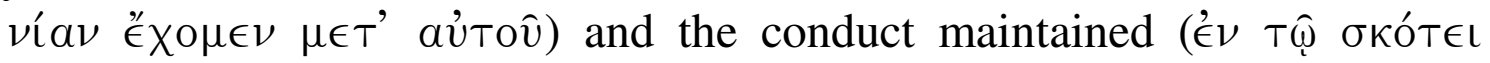
$\pi \epsilon \rho \iota \pi \alpha \tau \hat{\omega} \mu \epsilon \nu)$. The statement 'that we have fellowship with Him' claims that they have continuing fellowship with God, who is light. Contrary to this claim stands a course of conduct, 'and yet walk in the darkness.'

The verb 'walk' ( $\pi \in \rho \iota \pi a T \hat{\omega} \mu \epsilon \nu)$ is a common figure of speech to denote moral conduct; it marks a transition from the literal sense of the word to denote one's way of life (Bruce 1970:42; Danker 2000:803; Louw \& Nida 1988:509; Ebel 1978:945). It is used here in a semitic sense of 'to pursue a way of life', 'to live' or 'to conduct oneself' (Haas, De Jonge, Swellengrebel 1972:33). It characterizes a mode of existence (Bultmann 1973:17). The present subjunctive mode $(\pi \in \rho\llcorner\pi \alpha \tau \omega \hat{\mu} \mu \in \nu)$ denotes that it is a continuous action (Hiebert 1988:332) of living in sin.

Verses 8 and 10 relate to verse 6 in the sense that it is equally as wrong to deny, as a way of conduct, both human sinfulness ( $\mathrm{v} 8$ ) and the practice of $\sin (1: 10)$ in one's life. Such claims also hinder fellowship with both God and other believers in the family (cf. 1:6, 7). Such a person walks in darkness. It is not up to the children of God in the familia Dei to determine the paradigm and model of the 'walk'; it is determined by God's nature, 'as He himself is in the light.' This expression contemplates the contrast between God who 'is in the light' as the natural realm of his being, and those seeking fellowship with Him who must continuously endeavour to 'walk in the light'. The closer the fellowship with God and with those who walk with God, the more aware believers will be of sin in their lives (Johnson 1993:31).

In the apodosis of these verses $(1: 6,8)$ the Elder pronounced a condemnation on this conduct by stating that 'we lie' ( $\psi \in v \delta \delta ́ \mu \in \theta a$ / Éavtoùs $\pi \lambda \alpha \nu(\hat{\omega} \mu \in \nu)$. In his condemnation of these claims the Elder announces a verdict. In verses 6 and 8 he describes it as falsehood on man's part namely: 'we are not practicing the truth' (1:6); and 'the truth has no place in us' (1:8). But in verse 10 the Elder defines the condemnation even 
stronger, with reference to God. The claim to be without sin suggests falsehood on God's part; it 'makes him out to be a liar.' This proves that they do not have God's word abiding in them.

In all three cases (see 1:7, 9; 2:1f) the Elder raises the question of forgiveness, and in so doing replies once more to the heretical claim to be free from sin. In each of the three cases the Elder's answer is introduced by an adversative 'éá ('if'; here кaì є́áv 'but if'). Should believers walk in the light (1:7) or confess their sins (1:9) they will have fellowship with one another $(1: 7 b)$ and will be cleansed from all $\sin (1: 7 b, 9 b)$ by the blood of Jesus (1:7b) and because God is faithful and just (1:9b).

In 2:1, 2 this passage reaches a climax where the Elder twice deals positively with the problem of sin: if anyone should sin, God has made provision for this - (1) in the presence of God the Father, his children have a consummate intercessor, an Advocate (2:1, Jesus Christ the righteous) ${ }^{24}$ and (2) Jesus Christ is the consummate propitiation, the atoning sacrifice for the sins of the world. God's children are always under way and never stand before God as a finished product, but are always dependent on forgiveness (cf. Bultmann 1973:21).

Hence, according to this condition communion with God is:

- expressed in terms of: to walk in the light as He is in the light $(\dot{\epsilon} \nu$ T@̂

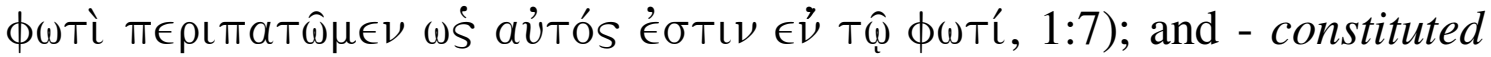
through: the acknowledgement-confession-forgiveness of sin; and the role

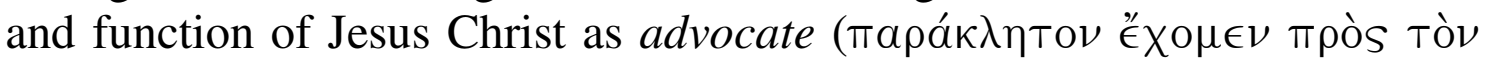

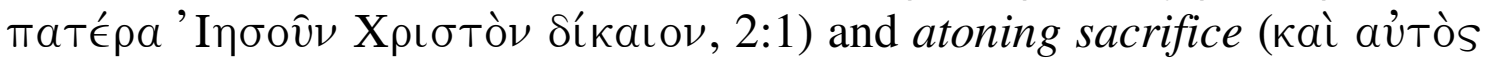

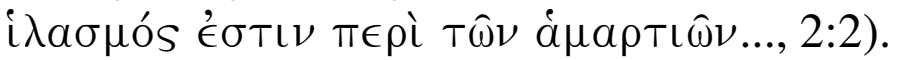

\subsection{The second condition for having fellowship with God: Be obedient} $(2: 3-11)$

The stylistic structure (a trio of false claims) in this sub-section, in several aspects is parallel to that of the preceding sub-section. Verse 3 states the theme that to know God means to follow his commandment. In verses 4, 6, and 9, three propositions of the false teachers are quoted, similarly to $1: 6$, 8 , and 10, but now introduced by the phrase 'he who says' (o $\lambda \lambda^{\prime} \gamma(\omega \nu)$. This trio of false claims relate to being in a right relationship with God/Christ: ${ }^{25}$ knowing God/Christ (2:4); abiding in God/Christ (2:6); being in the light (2:9). All the answers have in common: to emphasize 'the observance of the commandment of love' (cf. Johnson 1996:39). A tabled analysis of 2:3- 
11 where the Elder spells out the condition of being obedient is given below:

\begin{tabular}{|c|c|c|}
\hline AFFIRMATION & TEST & RESULT \\
\hline \multicolumn{3}{|c|}{ 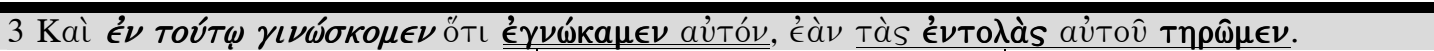 } \\
\hline 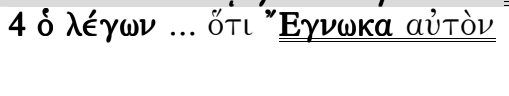 & 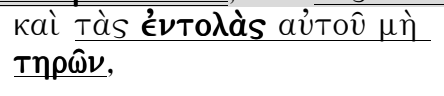 & 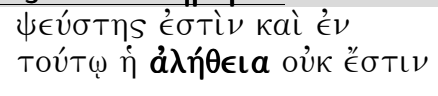 \\
\hline \multicolumn{3}{|c|}{ 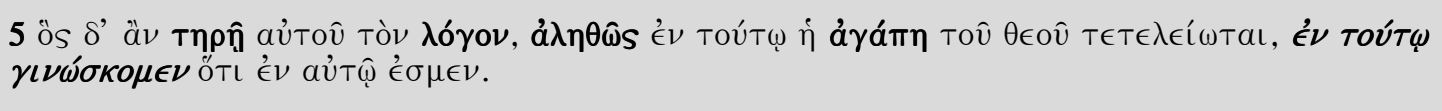 } \\
\hline 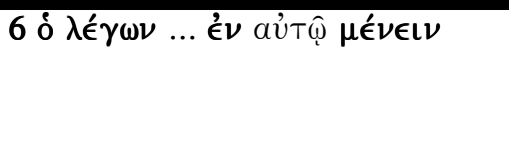 & 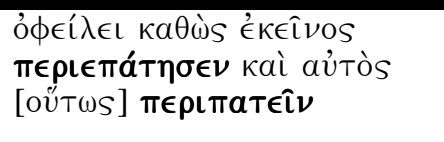 & 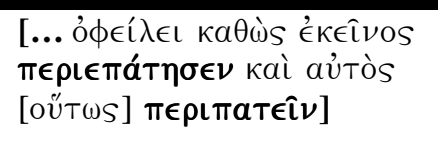 \\
\hline \multicolumn{3}{|c|}{ 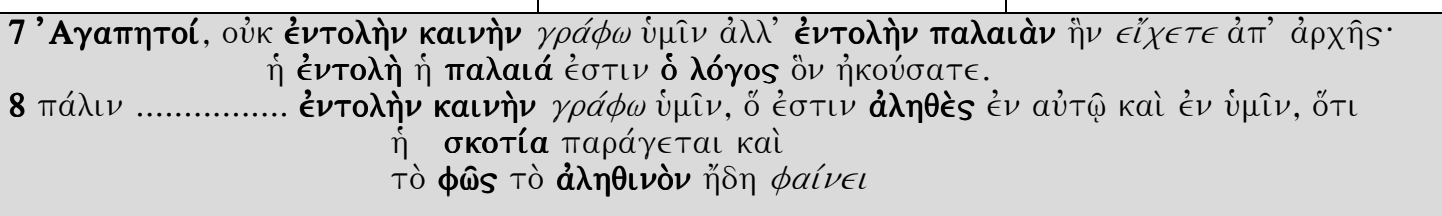 } \\
\hline 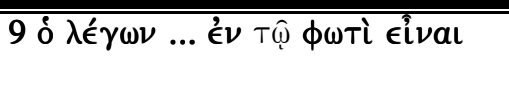 & 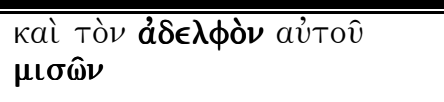 & 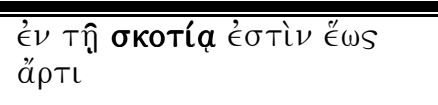 \\
\hline \multicolumn{3}{|c|}{ 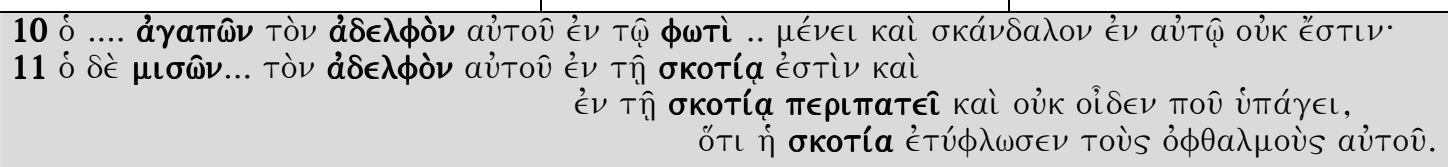 } \\
\hline
\end{tabular}

From this analysis it is clear that the progress of the Elder's thoughts in this passage is complicated, though carefully structured and developed. The vocabulary and literary form of this sub-section divide it into three units $(2: 3-5,6-8,9-11)^{26}$ to form three acts of behaviour in the development of the major theme, 'the observance of the commandment of love.' This

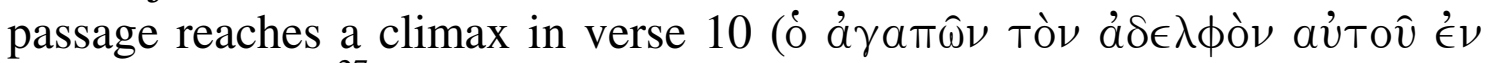
$\tau \hat{\varphi} \phi \omega T \grave{\imath} \mu \epsilon \in \nu \in \mathrm{l}) .{ }^{27}$ The three units will now be discussed.

\subsubsection{Adherence of the commands proves knowledge of God/Christ (2:3-5)}

This unit starts from the conviction that the behaviour of God's Children and their invisible relation to God are closely linked (cf. the preposition 'in' ['́ $\nu])$. Conclusions can be drawn from the one concerning the other. Accordingly, when they keep God's commandments it can be inferred that they know God which is the issue in 2:3-5. 
The verb 'to know' $(\gamma \iota \nu \omega \dot{\sigma} \sigma \in \iota \nu)$ occurs four times in these verses. Elsewhere in 1 John, 'to know God' means to have 'fellowship with God' (1:6; cf. John 17:3) and 'to walk in the light' (1:7; 2:9). This unit (2:3-5) highlights 'obedience to the commandments' as a criterion for fellowship with God the Father. ${ }^{28}$ From verse 3 it is apparent that observing the Father's commandments is a criterion of knowledge of Him. Knowledge and observance are correlative - in fact, obedience is the peak of the

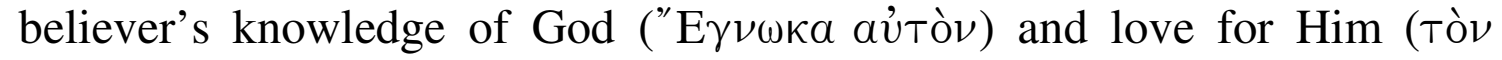
$\theta \epsilon \grave{\nu} \nu$ á $\gamma a \pi \hat{\omega} \mu \epsilon \nu$, cf. 5:2, 3). Obedience therefore constitutes fellowship

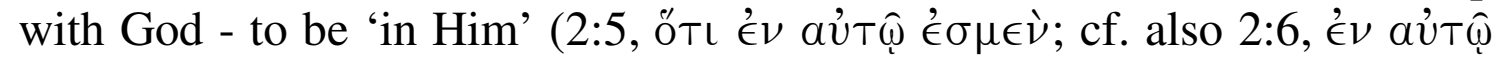
$\mu \in \in \in(\nu)$. Also in 2:5, the Elder emphasizes that the character of God will

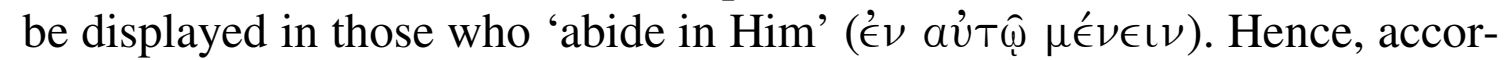
ding to this unit communion with God is:

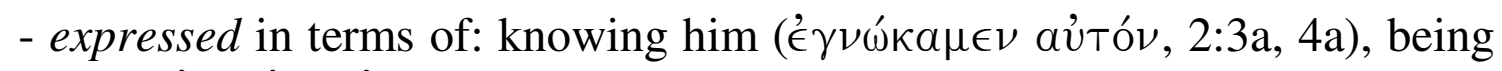

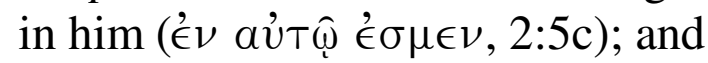

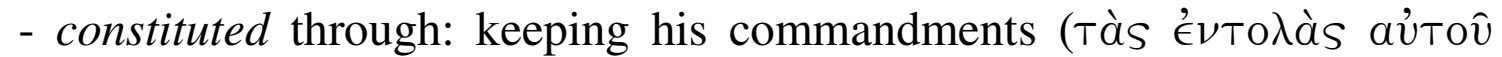

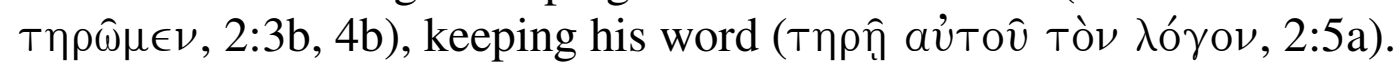

These expressions and constitution of communion with God is concisely phrased in the next unit (2:6) as 'to walk as he [Jesus] walked'; it moves God's children to imitate God's Son (1:3).

\subsubsection{To walk as Jesus walked proves to 'abide in him' (2:6-8)}

The imitation of Jesus is placed in this unit as the requisite and guarantee for communion with God the Father. Verse 6 extends the thought: those who abide in Him, has within themselves the sense of duty that moves them to imitate Jesus. This is expressed in terms of 'walk' ( $\pi \in \rho \iota \pi \alpha \tau \epsilon \hat{\imath} \nu$, 2:6). This is the obligation, therefore, laid personally upon every Christian believer (note the force of aútós, 'he himself'): not only to obey God's orders, his word (2:4-5), but also to follow the example of his Son (2:6). God's children cannot claim to abide in him unless they behave like him. As Jesus lived ( $\pi \in \rho \iota \in \pi \alpha ́ T \eta \sigma \in \nu$, aorist), so must Christians themselves live. $^{29}$

In the Johannine writings, the subordinating comparative particle, 'as' ( $\kappa a \theta \omega \dot{s}$ ), relates to the life of Christ as both a model to be imitated, and as the means for that imitation to become a possibility (cf. 3:2; 4:17; John 13:15, 34; 15:12, 17; also Malatesta 1978:134). Therefore, Jesus' conduct is presented as the source and example of all Christian obedience to the 
Father's commandments, of the indwelling of truth and God's love in believers and consequently of having fellowship with him and the Father. Hence, according to this unit, communion with God is:

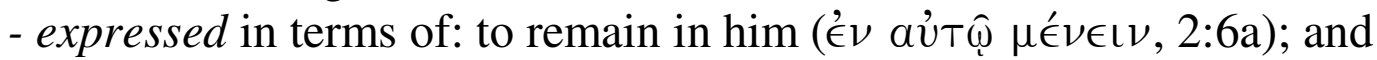

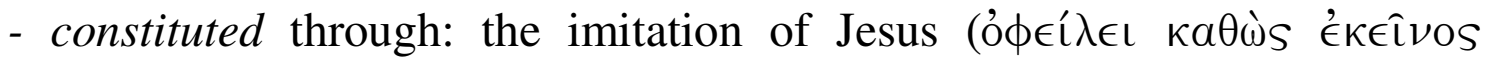

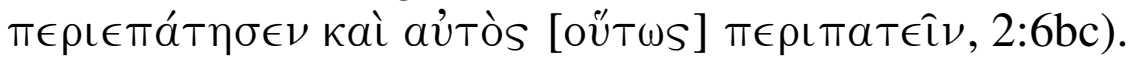

In the next two verses this imitation of Jesus is defined more closely in the references to the 'old' and 'new' commandment. The reference to the 'old' commandment is utilized by the Elder to understand the relation between the 'new' commandment and 'imitation' of Jesus. In 2:8a he states that he is writing to them a new commandment that is true in Christ and in the readers. In the gift of the new commandment the life-giving revelation

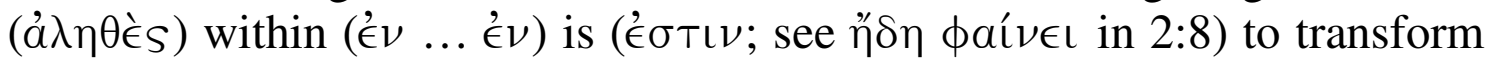

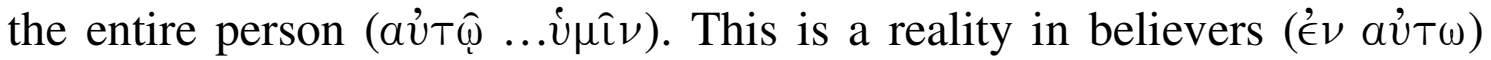
because it was first realized and continues to realize in Jesus ( $\dot{\epsilon} \nu \dot{v} \mu \hat{\imath} \nu$ ). By fulfilling the commandment in the familia Dei, the children of God will experience Christ, who is present and active through it, and also the Father, the ultimate source of it (Malatesta 1978:147).

This unit (2:8b) demonstrates how this law (which is both 'old' and 'new' in character) has been realized by Jesus. In the following unit the Elder turns to the content of the commandment. He now describes how love ought to realize (through Christ) in the experience and conduct of the Christian (2:9-11) as prove of living 'in the light.'

\subsubsection{To love one's brother is proof of living 'in the light' (2:9-11)}

The consequence and development of verses 6-8 are reflected in 1 John 2:9-11 and it contains three antithetical statements (negative [2:9]-positive [2:10]-negative [2:11]). These verses explain that the major criterion for judging the presence of fellowship with God, expressed in terms of knowledge of God the Father and of abiding in Him, is the observance of his commandment, epitomized in the new commandment of brotherly love. Through loving one another within the familia Dei believers will mutually experience God's love. This presupposes the abiding in his light (1:5), which has been incarnated in his Son and also mediated by his commandment of brotherly love. The observance of this commandment is made possible by God's own love, which indwells believers and impels them to imitate Jesus his Son, by placing within believers what was given to Jesus, namely the revelation of his commandment. According to this 
unit, fellowship with God is:

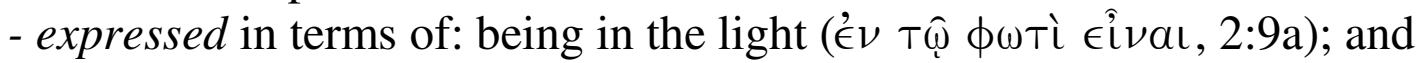

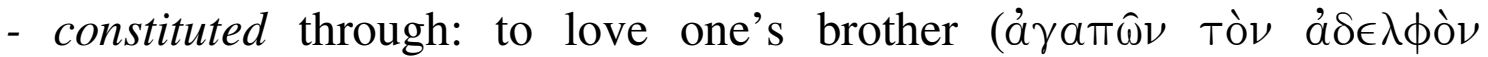

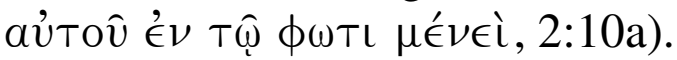

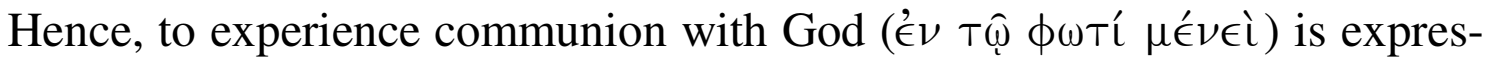
sed in this unit in active love for others within the family. It can therefore be concluded that the three affirmations about knowing God, abiding in him, and being in the light (as He himself is in the light, 1:7), are parallel versions of a single requirement that needs to be complied with, to be in a right relationship with the Father through the Son.

\subsection{The third condition for having fellowship with God: Doing God's will (2:12-17)}

Sub-section 2:12-28 consists of three units $(12-14,15-17,18-28)$ which, although distinct from one another, are nonetheless closely interrelated. ${ }^{30}$ In this sub-section the Elder requests his adherents' strengthening of their faith, by referring to seven reassurances (2:12-14; see also 2:20, o' $\delta a T \epsilon)$

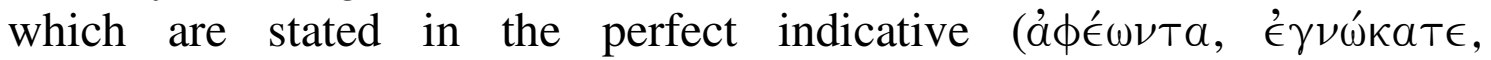
$\nu \in \nu \iota \kappa \eta ́ \kappa a \tau \epsilon ๋)$, four general truths $(2: 17,20,23)$ stated in the present

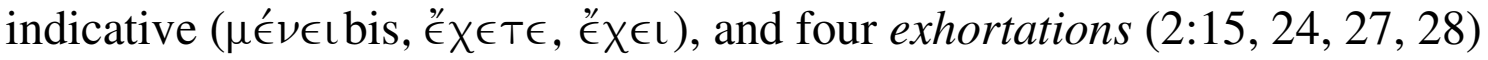

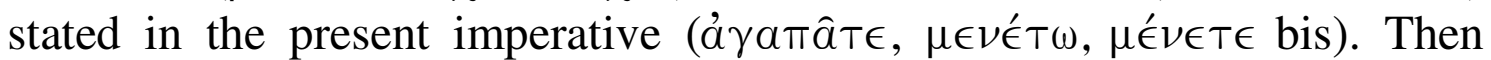
there are three promises $(2: 24,25,28)$ : the $1^{\text {st }}$ is stated in the future

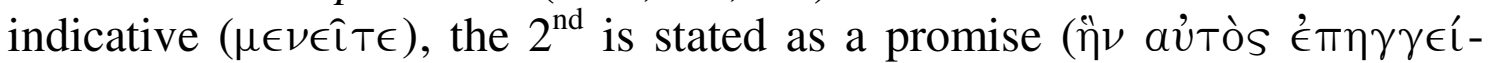
$\lambda \alpha \tau O)$, and the $3^{\text {rd }}$ with the future temporal particle ( $(\dot{\epsilon} \grave{\alpha} \nu)$.

The following is a tabled synopsis of 2:12-28 to point out the above analysis.

\begin{tabular}{|c|c|c|c|}
\hline REASSURANCES $^{31}$ & TRUTHS & $\begin{array}{c}\text { EXHORTATION } \\
\mathrm{S}\end{array}$ & PROMISSES \\
\hline 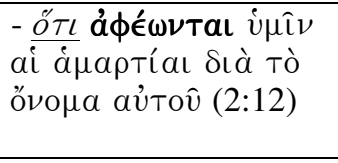 & 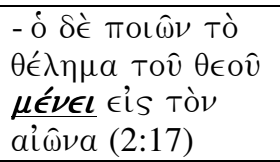 & 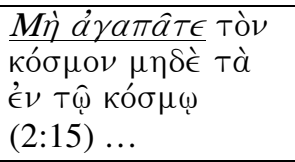 & \\
\hline 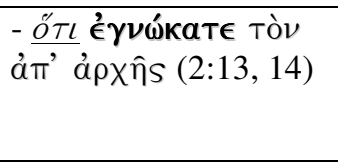 & 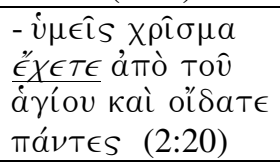 & & \\
\hline 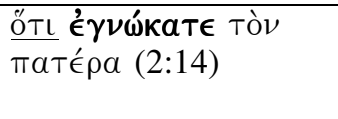 & & & 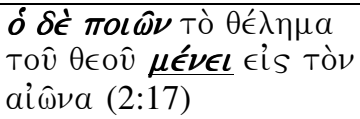 \\
\hline
\end{tabular}




\begin{tabular}{|c|c|c|c|}
\hline 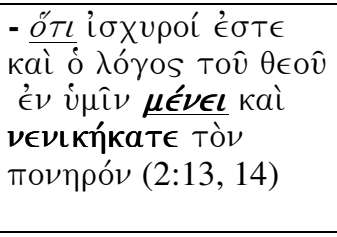 & 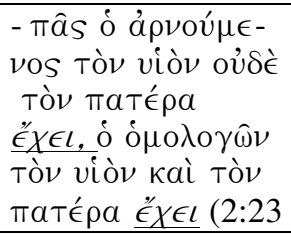 & 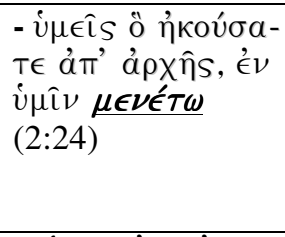 & 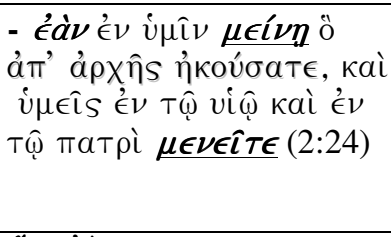 \\
\hline 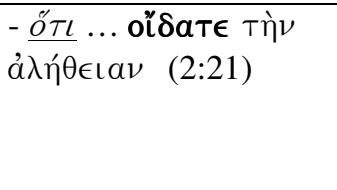 & 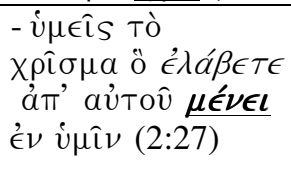 & 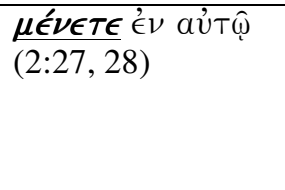 & 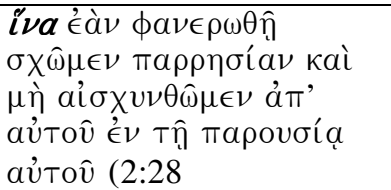 \\
\hline
\end{tabular}

The reassurances describe the character of those inside the familia Dei, as opposed to those outside, who falsely lay claim to faith. The Elder reminds them of their inner and personal experience of the effects of the Christian faith in their lives. They already experience fellowship with God. The general truths and promises are complementary to these reassurances. This is to strengthen them spiritually and has a rhetorical function to motivate them to fulfil the exhortations that are spelled out in this section. It contains a description of the life of those who live in the light, which is very different from the description of the life of the false teachers who live in darkness and who are not part of this group.

The exhortations in $2: 15,24$ and 27 (28) are stated by the Elder as conditions for enjoying communion with God. The first exhortation (2:15,

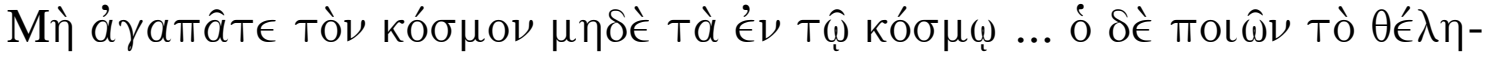

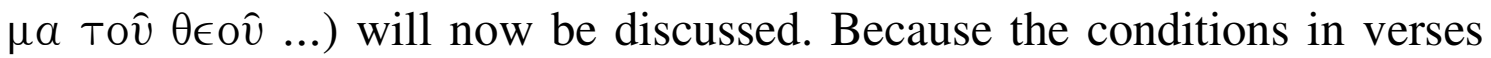
24, 27 and 28 relate, occur in the same unit and complement each other, they will be discussed concurrently as the fourth condition.

The third condition for having fellowship with God: Do not love the world or the things in the world, ... rather do the will of God (2:12-17)

From the previous tabled synopsis it is evident that verses 12-14 (also 2:21) are reassurances to strengthen the 'children of God' spiritually and to induce them not to love the world. In verses 15-17 three contrasts are spelled out why worldliness has to be rejected:

\begin{tabular}{|c|c|c|}
\hline Exhortation & The world & God (Father) \\
\hline 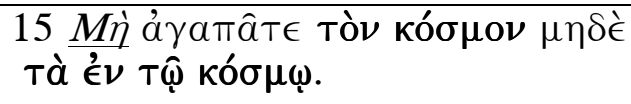 & 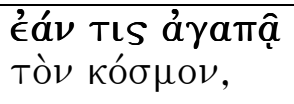 & 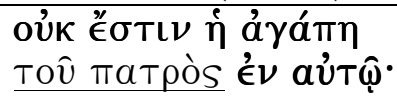 \\
\hline 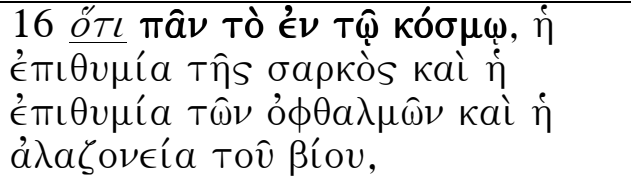 & 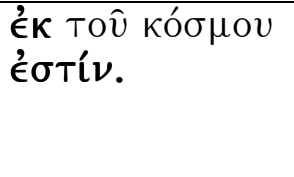 & 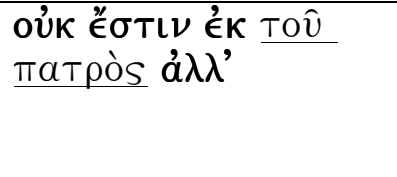 \\
\hline
\end{tabular}




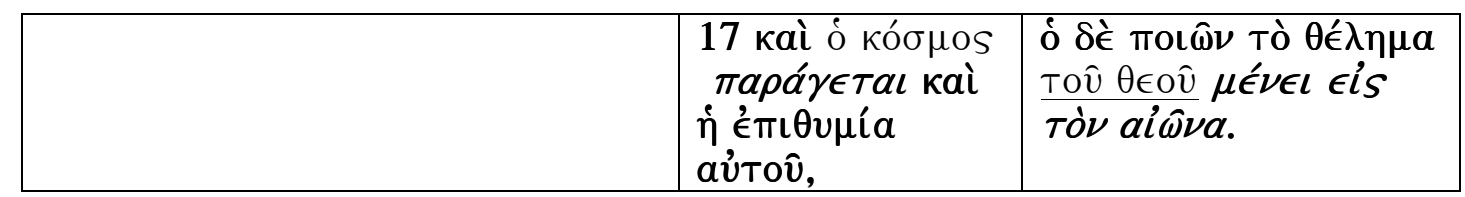

The first contrast (2:15) is between the love for the world and what is in it, and love for the Father. The community is exhorted not to love the world or the things in the world (2:15f). They must avoid the 'things in the world' that are at variance with the love of the Father in the familia Dei, because the world has no place for the love of the Father (2:15). The Elder wishes to show that these two loves are mutually exclusive. Those that are attached to the 'things in the world' cannot receive the Father's love, share that love with others, or love the Father in return. ${ }^{32}$

The second contrast (2:16), contrasts the origins of these internal attitudes. What is in the world, what represents the fallen human nature, is also from the world. Therefore, worldliness must be rejected. This implies that which is in God's children, namely, the love which reaches inwards towards the Father and outwards towards other family members, is from the Father.

In the third contrast (in duration) the Elder refers to the impermanent 'things in the world' as opposed to the permanency of life for those who 'do the will of God' (2:17). The emphasis in this section is placed on the

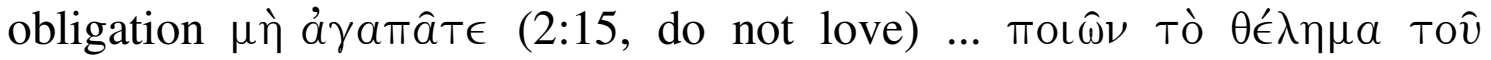
$\theta \in o \hat{v}$ (2:17, do the will of God) (also Strecker 1996:54). 'Doing the will of God' should be seen in relation to keeping his commands $(2: 3,4 ; 3: 22 ; 5: 2$, 3 ) and his word (2:5), ${ }^{33}$ which comprises acting according to the truth (see $1: 6)$ and living a 'sinless life' $(3: 6,9)$ in imitation of Jesus $(2: 6 ; 3: 3,7)$. To do God's will is to imitate Jesus to experience God through his Spirit (see the Fourth Gospel on the Paraclete) and to share in the victory won over the world by his obedience (John 14:30f; 16:33).

This unit reaches a climax when a promise is given to those "who do the will of God' (2:17): they 'will live forever.' This eternal life (life of God), promised to believers, is conceived in terms of their remaining not just forever, but remaining in the Son and the Father $(2: 24,25)$. It has both a chronological and quality meaning (Bultmann 1973:40). Obedience to the will of God in conformity with and through Jesus' own obedience will have the same effect in believers as in him: permanent communion with the Father. To love God means to do the Father's will and to share in his life.

Hence, according to this unit communion with God is: 


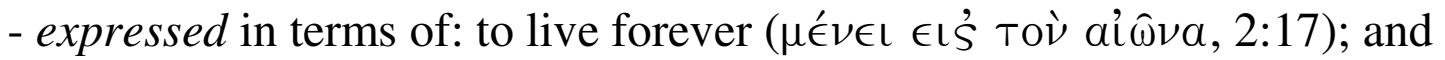

- constituted through: not to love the world ... to do the will of God

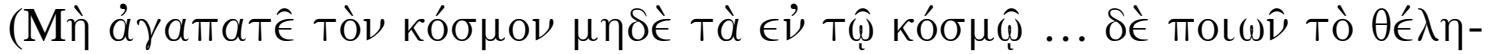

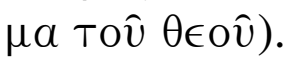

\subsection{The fourth condition for having fellowship with God: (2:18-28): Mutual Abidance}

This unit contains probably the greatest concentration and variety of the experience of fellowship ${ }^{34}$ to be found in any part of 1 John. All of these expressions are construed with the characteristic Johannine verb 'to abide' $\left(\mu \in \epsilon^{\prime} \nu \in \nu\right),{ }^{35}$ a feature which highlights the parenetic tone of this unit (Malatesta 1978:193). The positions that $\mu \in \operatorname{v\in l}$ occupies serve to blend the various facets which pervade the entire unit. ${ }^{36} \mathrm{~A}$ disposition of 2:12-28 reveals that the verb $\mu \epsilon \in v \in \mathrm{L}$ is the predominant theme, for it climaxes each of the three units $(2: 14,17 ; 27,28)$. It occurs once in $2: 12-14$ and once in $2: 15-17$, but seven times in $2: 18-28$.

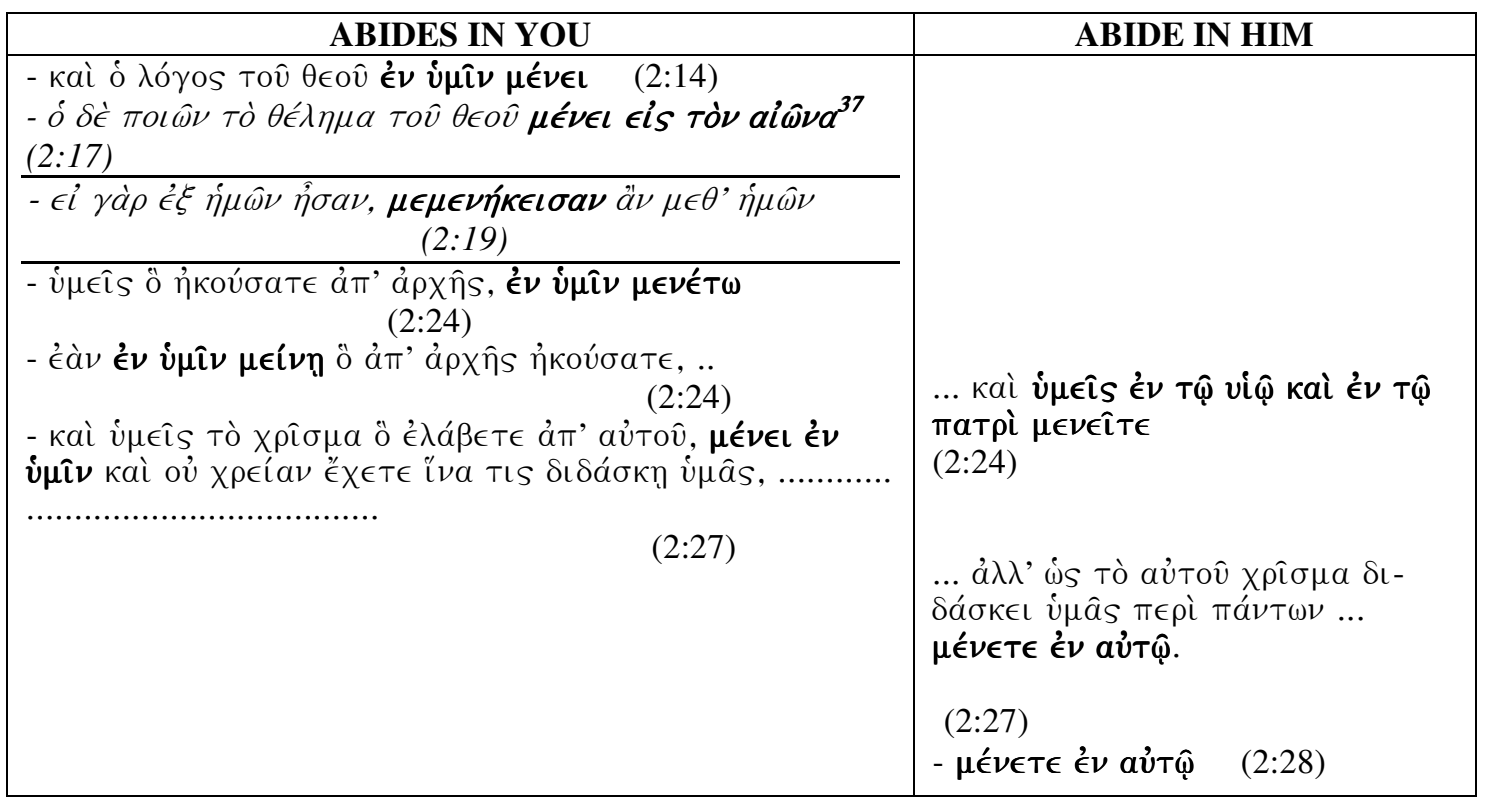

The instruction in this unit is aimed against the false teaching of the

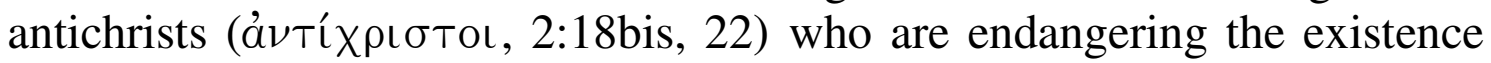
and fellowship of the community. To crack down on this false teaching of

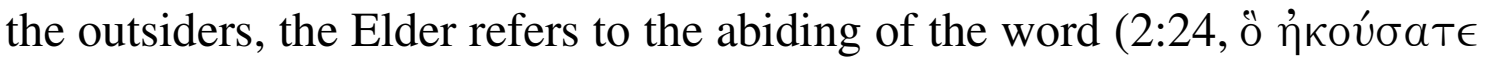

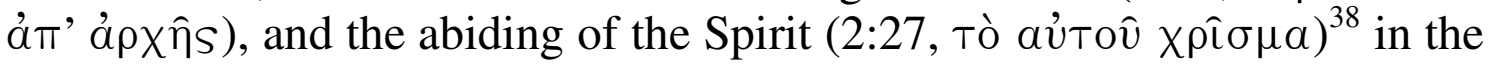
children of God. From 2:24 it is evident that it is the familia Dei that should hold on to the message from the beginning and thus enjoy that reciprocal 
fellowship with the Son and the Father ${ }^{39}$ (see also 1:3). If the word abides in them, then the Father and the Son will abide in them. ${ }^{40}$ Thus, the abidance of the $\operatorname{word}^{41}$ (and knowledge) in believers is a prerequisite and guarantee (Strecker 1996:68) for the abiding of the Father and Son in them. ${ }^{42}$ This is expressed here both in the present imperative $(\mu \in \nu \in \dot{T} T \omega)$ and in the future indicative $(\mu \in \mathcal{V} \in \hat{\imath} T \epsilon)$. Holding fast to the tradition on which the community was established is not something that happens once for all time; it does not lead to a perfection of faith. It must constantly recall this basis, and requires admonition so that it will continually realize anew what has been promised to it. The promise then of eternal life (2:25) expresses the confidence that abiding in the Father and in the Son will be perfected in the future (Strecker 1996:68f) when they will abide in the house of the Father.

But the Elder also speaks about the Holy Spirit within this context where the $\mu$ '́ $\nu \in \nu \nu$-motif, the reference to 'abide in God' and 'God abides in us' is prominent. The implications of the gift of the Holy Spirit focus strongly on the mutual 'abiding in' relationship between God (Christ) ${ }^{43}$ and his children (cf. Coetzee 1981:60). Heise (1967:112f) pointed out that the verb $\mu \in \operatorname{vel\nu }$ (with the exception of 2:6 and 3:6) occurs only in the closest connection with references to the Holy Spirit, when it is used regarding the relationship between God (Christ) and his children. ${ }^{44}$ Hence, the phrase 'remain in' ( $\mu \epsilon^{\prime} \nu \in T \in \dot{\epsilon} \nu$ ) expresses the most intimate relationship of 'fellowship'

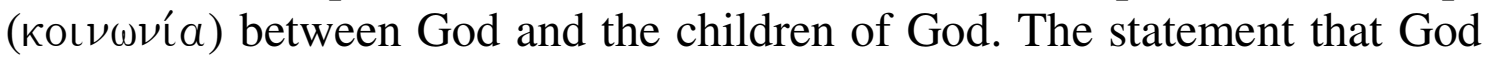
abides in his children has a mysterious element; it creates an inner unity, an unio mystica (cf. Munzer 1978:224).

This mutual abidance is not only approved by the Spirit (4:13), but is also constituted by the Holy Spirit $(3: 24 ; 4: 13)$. In this unit it is clear that the Spirit does not operate separate from, next to, or contradictory to the revelation ${ }^{45}$ of God in Christ, the proclaimed word. The Spirit is the Spirit of the teaching from the beginning ( $\left.\dot{\alpha} \pi^{\prime} \dot{\alpha} \rho \times \eta S\right)$. The truth $(\dot{\alpha} \lambda \eta \theta \in \dot{\epsilon} \alpha)$ which

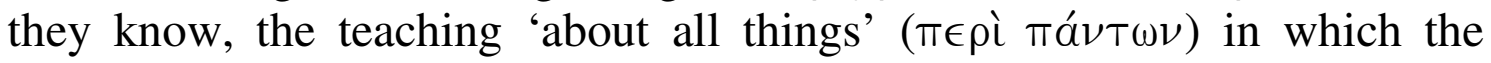
Spirit instructs them, is nothing less than 'what you have heard from the

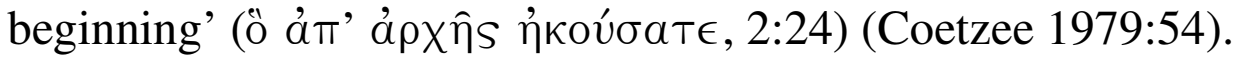

Hence, the verb 'abide' $\left(\mu \in v^{\prime} \in \nu\right)^{46}$ reflects this relationship between the Father, his Son and the children of God in the familia Dei. In this unit $\mu \epsilon \in \in \in \nu$ refers to a fully reciprocal experience. In this reciprocal use, of

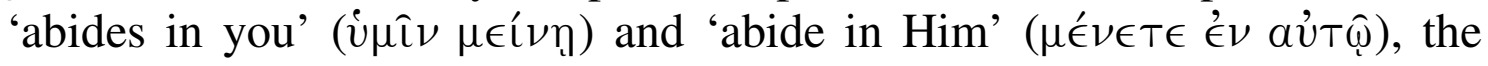
latter is not just another way of saying the former. That 'we abide in him 
and he in us,' (4:13) refers just as naturally to God's presence in his family, so that the evidence of the Spirit is a communal rather than an individual experience (see also $3: 24){ }^{47}$

After the analogy of the personal statement, the Elder uses 'abide in' for the expressions of the experience of divine life in God's children, for example God's Word (2:14); life (3:15); love (3:17); truth (2 John 2); anointing (2:27). God's children too abide in divine things, for example light $(2: 10)$; doctrine $(2: 14,24 ; 2$ John 9$){ }^{48}$

Hence, according to this unit communion with God is:

- expressed in terms of: you will abide in the Son and in the Father

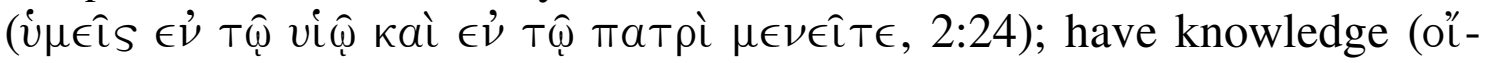

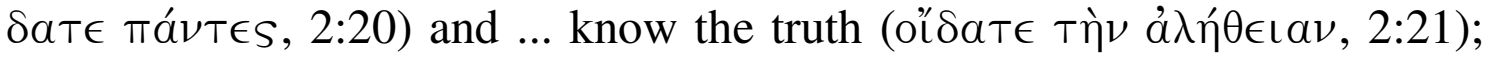
and

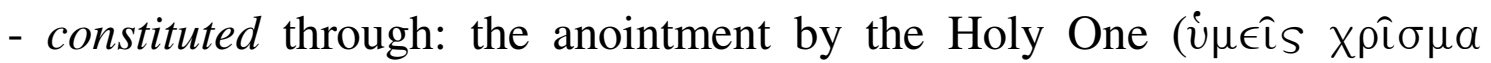

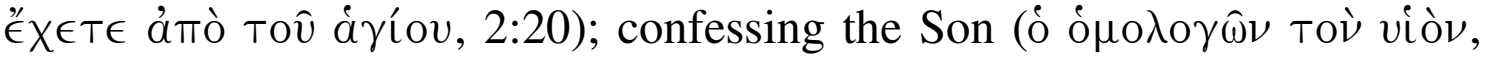
$2: 23$ ); to let what you heard from the beginning abide in you (i $\mu \in \hat{\imath} s$ ô

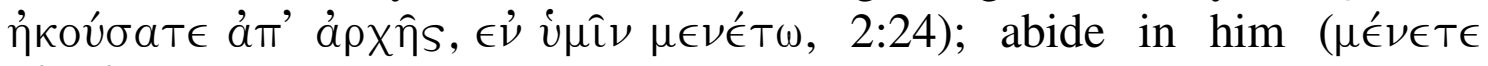

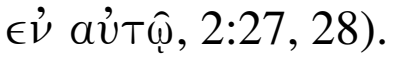

This unit, as well as the entire section, culminates with the eschatological reference in 2:28 that those who live in the light 'may have confidence and not be put to shame before him at his coming.'

\section{5. 'Experience of fellowship with God' demands the change of socio- religious behavior}

From this investigation it became evident that the identity and conduct of those inside the Johannine community are characterized differently from that of the outsiders. Their way of life, not only distinguished them from the outsiders, but also constituted the "experience of having fellowship with God'. They had to live mutually according to certain sacred-ethical prescriptions prescribed by the Elder.

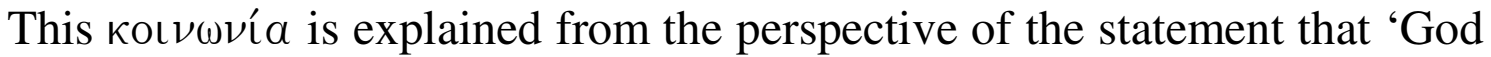
is light' (1:5; also 7). The 'light' metaphor not only describes a facet of God's nature (enlightenment, holiness and ethics), but it also indicates the character of the conditions necessary for all who seek fellowship with Him. The following synopsis is deduced from the perspective of 'God is light' to explain how 'fellowship' is constituted and maintained in the familia Dei. 
Enlightenment:

Ethics:
Holiness:

knowing him

have knowledge and
know the truth

being in him to remain in him; abide in him being in the light

abide in the Son and in the Father

let what you heard from the beginning abide in you

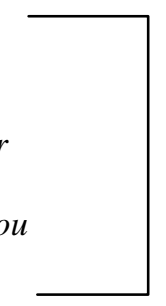

walk in the light as $\mathrm{He}$ is in the light confession of sin keeping his keep commandments,

keeping his word to do the will of God love one's brother not to love the world confessing the Son

to live forever

imitation of Jesus

It became evident that the believer's fellowship with God is an intimate mutual relationship. It may be represented as a mutual interpenetration, which is more than moral quality. God's personality and the believer are never compromised. It is an experience that is not limited to time, as in mysticism or ecstasy, but is in its very nature a permanent position ('to abide'; 'to know'; 'to keep') as long as those insiders 'walk in the light' to form a sanctorum communitas (holy community).

Within the familia Dei, the Téкva $\theta \in \mathrm{O} v$ are free to choose between light (ó

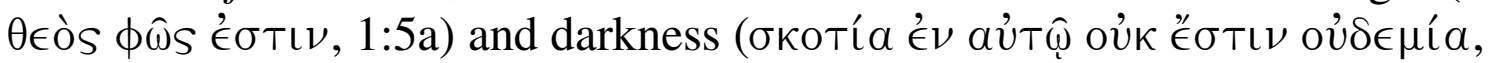

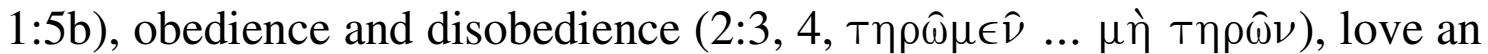

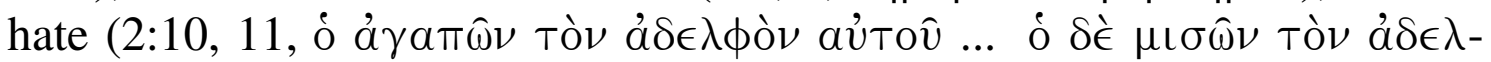
фòv aủTôิ). In order to help his adherents to make the right decision, the methodology used by the Elder in 1 John has both (1) an explanatory function and (2) a rhetorical function. The Elder uses the reciprocal negative (antithetical parallelism) to describe and to explain the commanding positive. The rhetorical function is to encourage his adherents to keep on living in the light, and to encourage those who were led astray to come back 'to live in the light' in order to experience fellowship. Therefore each sub-section builds up to and ends on a climax. In fact, the entire section (1:5-2:28) is a logical rhetorical building up to an eschatological climax: 


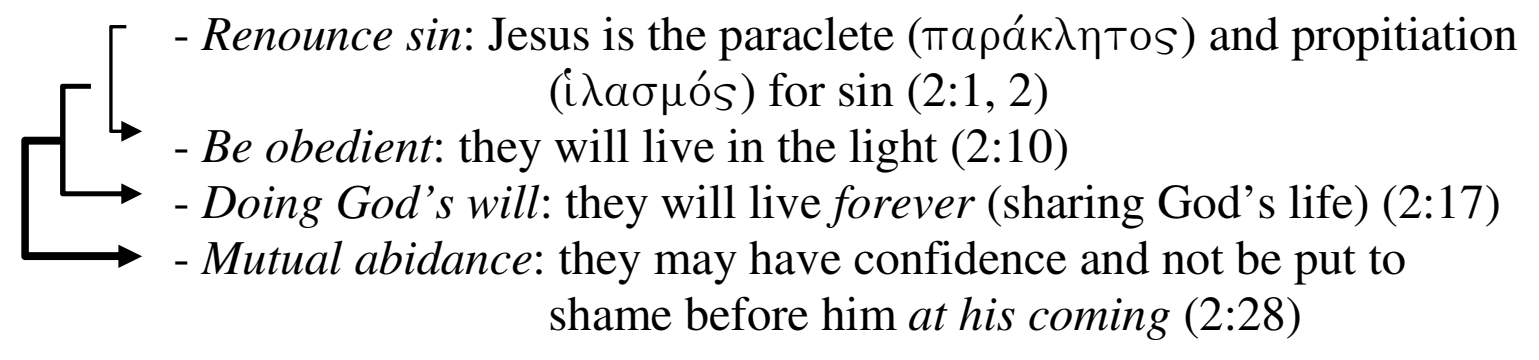

\section{BIBLIOGRAPHY}

Brown, R.E. 1982

The Epistles of John (AB). New York: Doubleday.

Brown, R.E. 1997

An Introduction to the New Testament. London: Doubleday. Bruce, F.F. 1970

The Epistles of John. London: Pickering \& Inglis Ltd.

Bultmann, R. 1973

The Johannine Epistles (A Commentary on the Johannine Epistles).

Philadelphia: Fortress Press.

Callahan, A.D.

A Love Supreme: A History of the Johannine Tradition. Minneapolis:

Fortress Press.

Coetzee, J.C. 1981

The Holy Spirit in 1 John. Neotestamentica 13, 43-67.

Culpepper, R.A. 1995

1-2-3 John in The General Letters (Proclamation Commentaries).

Edited by Krodel, G. Minneapolis: Fortress Press.

Culpepper, R.A. 1998

The Gospel and Letters of John. Nashville: Abingdon Press.

Danker, F.W. (ed) 2000

Greek English Lexicon of the New Testament and other Early

Christian Literature. $3^{\text {rd }}$ Edition BDAG. Chicago: University of Chicago Press.

Derickson, G.W. 1993

What is the Message of 1 John?. BSac 150, 89-105.

Dodd, C.H. 1953

The Johannine Epistles. London: [S.I.] Hodder and Stouton.

Duling, D.C. 2003

The New Testament: History, Literature, and Social Context. Belmont:

Wadsworth / Thomson.

Du Rand, J.A. 1981

A discourse analysis of 1 John. Neotestamentica 13, 1-42. 
Ebel, G. 1978

$\Pi \epsilon \rho ı \pi a T \epsilon ́ \omega$ in DNTT (Vol 3). Edited by C Brown. Exeter: The Paternoster Press.

Edanad, A. 1987

Christian existence and the New Covenant. Bangalore: Dharmaran Publications.

Edwards, R.B. 1996

The Johannine Epistles. Sheffield: Sheffield Academic Press.

Edwards, R.B. 2000

The Johannine Epistles, in The Johannine Literature. Edited by

Lindars, B, Edwards, R.B. \& Court, J.M. Sheffield: Academic Press.

Gräbe, I. 1992

Metafoor in Literêre terme en teorieë. Edited by Cloete T T. Pretoria:

HAUM-Literêr.

Grayston, K. 1984

The Johannine Epistles (The New Century Bible Commentary). Grand Rapids: Eerdmans.

Günther, W. 1975

Nıкáw in DNTT. Edited by Brown C. Exeter: The Paternoster Press.

Haas, C., De Jonge, M. \& Swellengrebel, J.L. 1972

A Translater's Handbook on the Letters of John. London: United Bible Societies.

Hanse, H. 1978

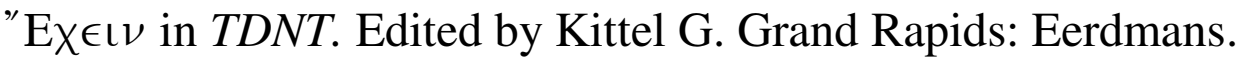
Harland, P.A. 2003

Associations, Synagogues and Congregations. Claiming a Place in Ancient Mediterranean Society, Minneapolis: Fortress Press.

Hauck, F. 1967

Mév( $)$... in TDNT. Edited by Brown C. Exeter: Paternoster Press.

Heise, J. 1967

Bleiben. Menein in den Johanneischen Schriften. Tübingen: Mohr.

Hiebert, D.E. 1988

An Exposition of 1 John 1:1-4. BSac 145, 197-210.

Hurtado, L.W. 2003

Lord Jesus Christ (Devotion to Jesus in Earliest Christianity). Grand Rapids: William B. Eerdmans.

Johnson, T.F. 1993

1, 2, and 3 John (New International Biblical Commentary). Peabody: Hendrickson Publishers.

Jordan, W.J. 1974

Aristotle's concept of Metaphor in Rhetoric in Aristotle: the classical 
heritage of rhetoric. Edited by Erickson, $\mathrm{K}$ V. Metuchen, NJ: Scarecrow Press.

Joyce, J.D. 1960

The Second Testament Witness to the Light: An Essay in Biblical Theology. Encounter 21 (Winter), 3-20.

Kenney, G.C. 2000a

The Relation of Christology to Ethics in the First Epistle of John. New

York: University Press of America.

Kenney, G.C. 2000b

Leadership in John. An Analysis of the Situation and Strategy of the

Gospel and the Epistles of John. New York: University Press of America.

Klauck, H-J. 1991

Der Erste Johannesbrief (EKK). Zürich: Benziger Verlag.

Kloppenborg, J.S. 1996

Collegia and Thiasoi. Issues in Function, Taxonomy and

Membership," in Voluntary Associations in the Graeco-Roman World.

Edited by Kloppenborg, J S \& Wilson, S G. London: Routledge.

Kotzé, P.P.A. 1981

The meaning of 1 John 3:9 with reference to 1 John 1:8 and 10 .

Neotestamentica 13, 68-83.

Krimmer, H. 1989

Johannes-Briefe (Bibel-Kommentar Band 21). Neuhausen Stuttgart:

Hänssler-Verlag.

Ladd, G.E. 1998

A Theology of the New Testament. Grand Rapids: William B Eerdmans.

Ladd, G.E. (1991) 1997

The Theology of the Johannine Epistles (New Testament Theology).

Cambridge: University Press.

Lieu, J. 1991

The Theology of the Johannine Epistles (New Testament Theology).

Cambridge: Cambridge University Press.

Louw, J.P. \& Nida, E.A. 1988

Greek-Enlish Lexicon of the New Testament based on Semantic

Domains (vol 1). New York: United Bible Societies.

Malatesta, E. 1978

Interiority and Covenant. Rome: Biblical Institute Press.

Malina, B.J. 1996

The social world of Jesus and the Gospels. London: Routledge.

Munzer, K. 1978 
Remain in DNTT edited by Brown. Exeter: Paternoster Press.

Onions, C.T. (ed.) 1984

The Shorter Oxford Dictionary on historical principles. Oxford:

Clarendon Press.

Painter, J. 2002

1, 2, and 3 John. Collegeville: The Liturgical Press.

Rusam, D. 1993

Die Gemeinschaft der Kinder Gottes. Stuttgart: Verlag W. Kohlhammer.

Ricoeur, P. 1978

The Metaphorical process as cognition, imagination and feeling. Critical Inquiry 5, 143-159.

Schattenmann, J. 1975.

'Fellowship' in DNTT (Vol 1). Edited by C Brown. Exeter: The Paternoster Press.

Schnackenburg, R. 1992

Die Johannesbriefe (HThK 13/3). Freiburg: Verlag Herder (HTKNT). Schweizer, E. 2000

An Exegetical Analysis of 1 John 1:7, in Theology in the Service of the

Church. Edited by W M Alston. Grand Rapids: William B Eerdmans.

Smalley, S.S. 1984

1, 2, 3 John (WBC, vol 51). Dalas: Word Books.

Smalley, S.S. 1978

John: Evangelist and Interpreter. Exeter: Paternoster Press.

Smalley, S.S. 1998

1, 2, 3 John (WBC, vol 51). Dallas: Word Books.

Stott, J.R.W. 1964

The Epistles of John. An Introduction and Commentary. Tyndale New

Testament Commentaries. Leicester: Inter-Varsity Press/Grand

Rapids: Wm. B. Eerdmans Publishing Co.

Strecker, G. 1996

The Johannine Letters (A Commentary on 1, 2, and 3 John). Minneapolis: Fortress Press.

Thomas, J.C. 2004

The Pentecostal Commentary on 1 John, 2 John, 3 John. Cleveland:

The Pilgrim Press.

Van der Merwe, D.G. 2004

Salvation in the Johannine Epistles. HTS 60 (1 \& 2), 533-554.

Van der Merwe, D.G. 2005

Salvation in the Johannine Epistles, in Salvation in theNew Testament:

Perspectives on Soteriology. Edited by J.G. Van der Watt. Leiden: 
Brill.

Van der Merwe, D.G. 2006

'Having fellowship with God' according to 1 John: dealing with the intermediation and environment through which and in which it is constituted. (waiting for publication in Acta Theologica).

Van der Watt, J.G. 1999

Ethics in First John: A Literary and Socio-scientific Perspective. $Q B C$ 61, 491-511.

Van der Watt, J.G. 2000

Family of the King (Dynamics of Metaphor in the Gospel according to John). Leiden: Brill.

Vorster, W.S. 1975

Heterodoxy in 1 John. Neotestamentica 9, 87-97.

Vitrano, S.P. 1987

The Doctrine of Sin in 1 John. AUSS 25, 123-131.

Von Wahlde, U.C. 1990

The Johannine Commandments (1 John and the Struggle for the Johannine Tradition). New York: Paulist Press.

Westcott, B.F. 1982 (1883)

The epistles of St John (Johannine studies since Westcott's day by F F Bruce). Grand Rapids: William B Eerdmans.

Wilson, S.G. 1996

Voluntary Asssociations. An Overview in Voluntary Associations in the Graeco-Roman World. Edited by Kloppenborg, J.S. \& Wilson, S.G. London: Routledge.

Whitacre, R.A. 1982

Johannine Polemic: The Role of Tradition and Theology (SBL Dissertation Series 67). Chico: Scholars Press.

\section{NOTES}

This is sensible not only from the huge number of books and articles published on spirituality as a concept, but also from the interest on tertiary level . Even in South Africa, a Spirituality Association of South Africa (SPIRASA) was established at Stellenbosch in 2004. At some universities in South Africa, quite a number of students have enrolled for graduate and postgraduate studies in spirituality. At the University of Pretoria the Faculty of Theology's theme for 2004 was 'Spirituality'.

2 This statement does not negate the interest in spirituality also in the Lutheran, Catholic, Orthodox or Reformed traditions. 
See Van der Merwe (2006) for a more thorough discussion of the concept

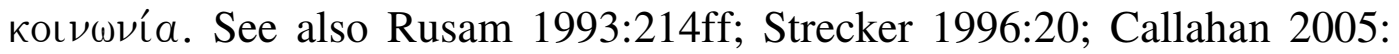
$18,22$.

4 In this article it has been accepted, in agreement with the point of view of most scholars, that the three Johannine epistles were written by the same person, referred to in 2 John 1 and 3 John 1 as the $\pi \rho \in \sigma \beta u ́ t \epsilon \rho o s$ (Brown 1997:398; Culpepper 1998:251; Kenney 2000b:12; Duling 2003:439; Thomas 2004:4; Callahan 2005:2). Therefore, in this document, the author will be referred to as 'the Elder'.

5 The above understanding by Haas-De Jonge-Swellengrebel is supported by Danker and Louw-Nida. Danker (2000:552) defines it lexicologically as 'close association involving mutual interests and sharing, communion, fellowship, close relationship'. Thus, according to Danker, in the context of

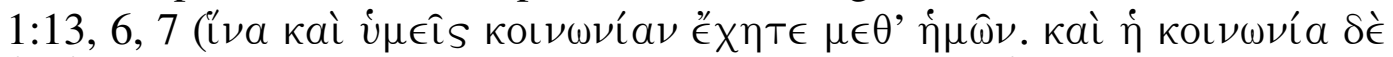

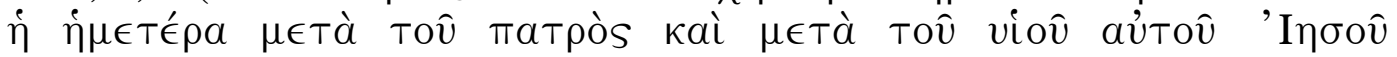
Xрıбтоิ), it would mean 'to have fellowship with someone'. Louw \& Nida

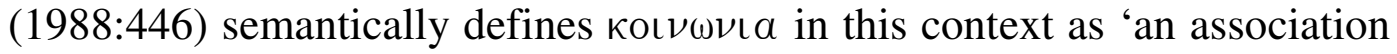
involving close relations and involvement - "close association, fellowship".' Schattenmann (1975:644) attenuates it theologically to mean 'to fellowship in faith', but is correct that it does not refer to a mystical fusion with Christ and God.

6 Painter (2002:138) emphatically states that 'It is fundamental to the message of 1 John that relationship (koinônia) with God (the Father and the Son) is through the relationship (koinônia) with one another: see 4:7-8, 1112, 20-21; 5:1-3.'

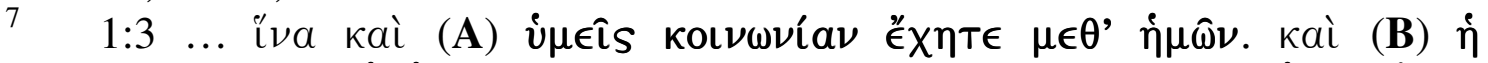

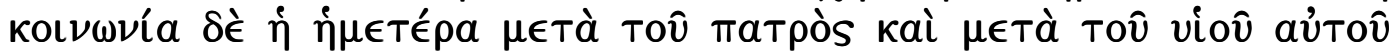

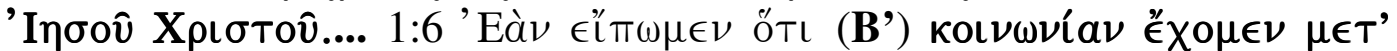

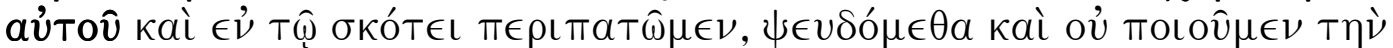

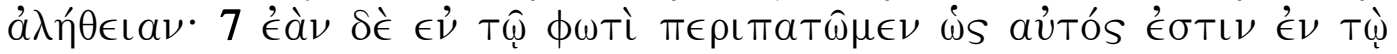

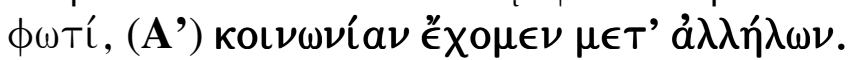

8 The comprehensive work of Robbins (1996, Exploring the texture of texts: $a$ guide to socio-historical interpretation) will be used in this regard.

9 Within scholarship two distinct and disparate views have developed concerning the message of 1 John. They have arisen as a consequence of two variant perceptions of the purpose of the epistle. The one comprises "salva-

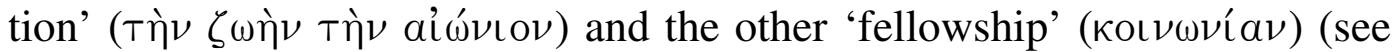
Derickson 1993:89-105; cf. also Smalley 1984; Kenney 2000a). In fact they are complementary to one another. Both these themes are mentioned in the prologue of 1 John, where the author gives, as we may expect, a synopsis of his principal motifs. In this article the emphasis will fall on the fellowship perspective according to the first section (1:5-2:28) where God is referred to as: ò $\theta \in \hat{s} s \phi \hat{\omega} s \hat{\epsilon} \sigma \tau \iota \nu$ (1:5). The other two major sections are 
2:29-4:6 and 4:5-12. Compare Malatesta 1978, Von Wahlde 1990, Culpepper 1998, Kim 1998, Kenney 2000a and Painter 2002, who basically use the same structural division.

According to the following scholars is 'Walking in the Light as a Sign of Fellowship with God' the central theme of 1:5-2:11, (17), (28): Haas, de Jonge, Swellengrebel 1972:14f; Bultmann (1973:15; Malatesta 1978:93; Schnackenburg 1992:70, 72; Strecker 1996:23; Edwards 1996:71. The unit, 2:18-28, has been added because it contains probably the greatest concentration and variety of the experience of fellowship to be found in any one sub-division of 1 John.

Johnson (1993:30) points out that 'Just as in the Sermon of the Mount, God's character is the pattern and model (Matt. 5:48: 'Be perfect, therefore, as your heavenly Father is perfect'), and just as Paul told the Philippians,' 'Let your manner of life be worthy of the gospel' (Phil 1:27, RSV). So the Elder holds up a divine standard for human conduct.

Alongside to 'have fellowship with God,' which is only found in 1:3 and 6,

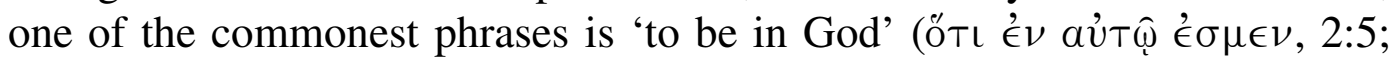

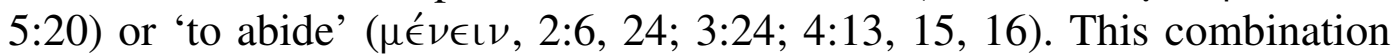
with the typical verb $\mu \epsilon \in \omega$ is usually expanded (except in 2:6, 24) into a twofold or reciprocal formula ('we in God and God in us') or vice versa. Another expression of fellowship with God found only in 1and 2 John is 'to

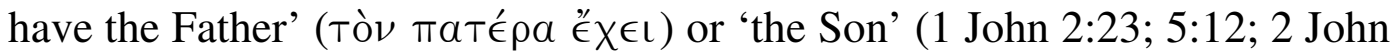

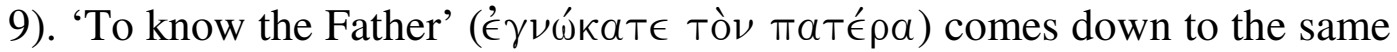
thing $(2: 3$ [cf. 2:5]; 2:13, 14 [cf. 1:3]). Believers are also indicated to be 'of

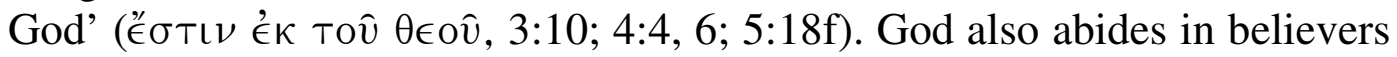

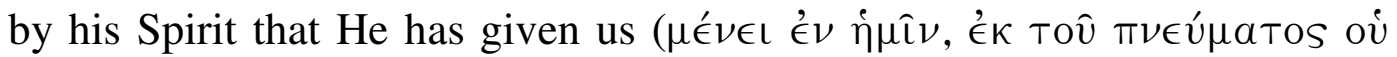

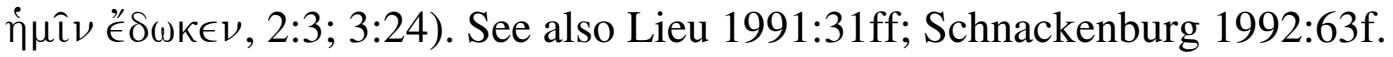
Judge, E A 1960. The Social Pattern of the Christian Groups in the First Century. London: Tyndale Press.

13 Nuanced differences occur among scholars on the interpretation and

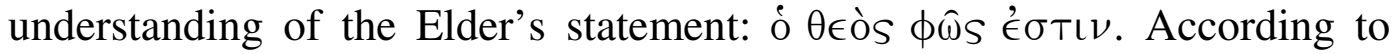
Smalley (1984:20) it is 'a penetrating description of the being and nature of God: it means that he is absolute in his glory (the physical connotation of light), in his truth (the intellectual) and in his holiness (the moral).' Krimmer (1989:26; cf. also Schnackenburg 1992:77) sees this metaphoric reference as 'eine Seinsaussage und eine Handlungsbeschreibung Gottes'. For Bultmann (1973:16) it designates God's nature, and the sphere of the divine. Malatesta (1978:96ff) tries to relate the meaning to what the Bible says about the relation between God and light. Haas, De Jonge and Swellengrebel (1972:32) suggest a shift from metaphor to simile, 'God's being is like light.' 


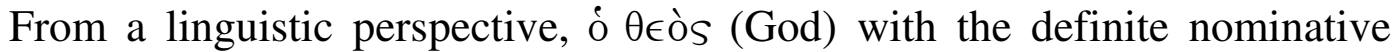
article, is the subject; $\phi \hat{\omega} s$ (light), without the article, is also nominative and subjective; therefore the two terms and subjects cannot be interchanged. The qualitative predicate noun, $\phi \hat{\omega} s$, is used in a qualitative sense (Haas, De Jonge, Swellengrebel 1972:31), to describe God as possessing the qualities of light. This is a reflection of God's nature. Therefore, $\phi \hat{\omega} s$ should not be interpreted literally (Hiebert 1988:331).

The best way then to do justice to what is meant by using this metaphor by the Elder is to turn the entire process of interpretation around. One has to consider the context (1:6-2:28) following this statement in 1:5. The text discusses three moral conducts (do not sin, obey God's commandment, and do not love the world, but do the will of God). This becomes only possible through mutual abidance (living in the sphere of God). Thus, we can conclude that the light metaphor refers to God's nature (Bultmann 1973:16; Strecker 1996:25; Johnson 1993:28) and the sphere of the divine (as according to Bultmann 1973:16) with ethical implications for the "children of God' (as according to the majority of scholars: Painter 2002:128; Hiebert, 1988:331; Haas, De Jonge and Swellengrebel, 1972:32; Bruce, 1970:41; and Whitacre, 1982:161). Thus God's nature demands a specific way of conduct within the sphere of the familia Dei.

The Oxford Dictionary (1984:1387) helps to understand what is meant by referring to God's nature in its definition of nature as: '(1) the essential qualities of a thing; the inherent and inseparable combination of properties essentially pertaining to anything and giving it its fundamental character, (2) The inherent and innate disposition or character of a person.'

'A surface metaphor is a basic metaphor in which both the tenor and vehicle are given' (Van der Watt 2000:20).

Jordan (1974:234, 236) points out Aristotle's reference concerning the 'affective aspect of meaning' in relation to metaphors: 'Aristotle's concept of metaphor is essentially psychological in that it identifies semantic and structural characteristics, which affect reader and listener behaviour. ... The meaning ... is neither the denotation nor the referent but the mental experience which the word evokes in a listener.'

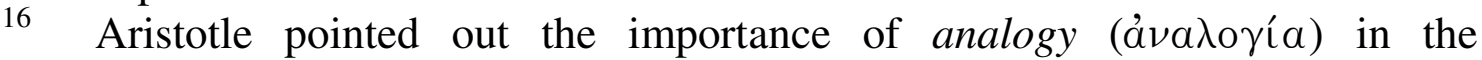
functioning of metaphors (Aristotle Poet.21). Analogy is used here to identify similarity (congruency) between the tenor and the vehicle of this metaphor, which simultaneously contains and expresses the difference (incongruency) between the two (see Ricoeur 1978:148). That is why the two metaphorical elements, of $\dot{o} \theta \epsilon o ̀ s$ and $\phi \hat{\omega} s$, are not equal to one another, but are called 'analogically'.

Hiebert (1988:331) adds an intellectual perceptive. 
See Stott (1964:70), Dodd (1953:201-205) and Malatesta (1978:99ff) for a discussion on the image of God as 'light'.

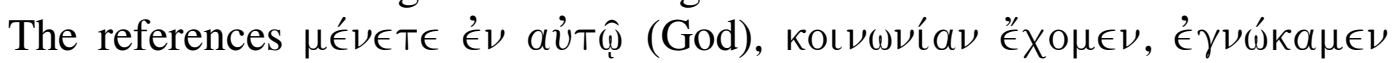

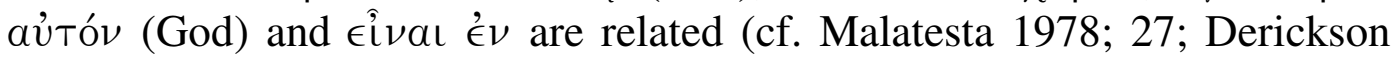
1993:97), though understood as describing aspects of 'walking in the light' and the believer's relationship to the Father within the familia Dei. According to Derickson (1993:97) who studied the message of 1 John,

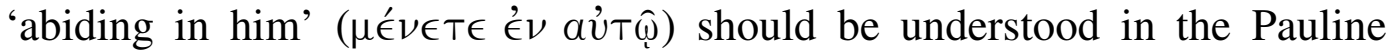
sense of 'walking in the Spirit.' This is supported in part from the Johannine

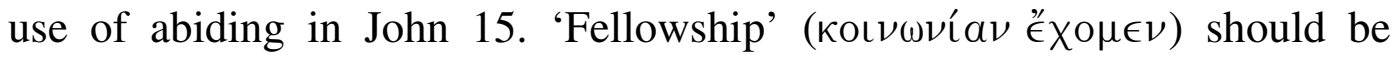
understood naturally as expressing relationship or communion. 'Knowing God' is the result of walking with Him in fellowship.

Most of the references to sin are in the singular. This entails that it calls attention to the principle or fact of $\sin$ in human life (e.g. 1:8), rather than individual acts of sin.

This stylistic feature is important. It indicates the discourse structure of this whole section (Haas, De Jonge \& Swellengrebel 1972:34).

These claims seem clearly to represent views advanced by the false teachers (Hiebert 1988:332; Culpepper 1998:257; Hurtado 2003:414). Hiebert (1988:332) interprets all three the claims in 1:6, 8, 10 as 'hypothetical.' To interpret it as 'expectational' claims seems to be closer to the truth.

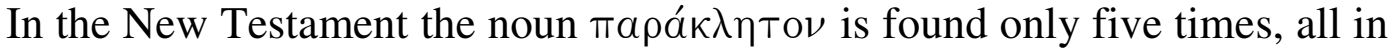
the corpus Johanneum (John 14:16; cf. 14:26; 15:26; 16:7). Whereas

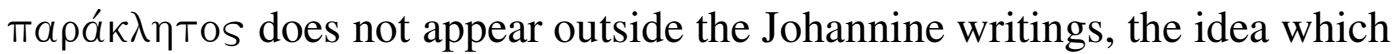
it conveys is embedded in primitive Christian teaching. Paul refers to the Spirit as the one who 'intercedes for us' (Rom 8:26, 27) and describes Jesus as the one 'who is at he right hand of God, who also intercedes for us' (Rom 8:34). Even in the Epistle to the Hebrews, advocacy forms part of Christ's intercessory ministry as his people's high priest (e.g. Heb 7:5). For its use and meaning in John's Gospel, and for the difficulty of translating the term exactly, see Smalley (1978:228-33).

In this sub-section no explicit references to God or Christ occur. Even from the context it is not always clear to which person the personal pronouns or verbs refer.

In this sub-section (2:3-11), three central affirmations ( $\dot{\delta} \lambda \epsilon \epsilon^{\prime}(\omega \nu, 2: 4,6,9)$ occur, of which the first two legitimize the act of 'obedience':

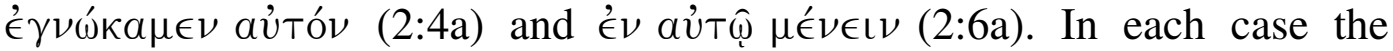
validity of the claim is shown to be tested and established by a practical condition (cf. 2:5, 6b). The tests attached to these affirmations,

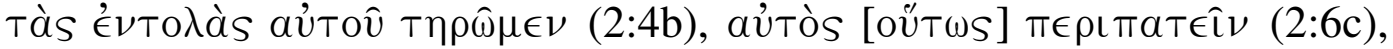
have to be understood as a progressive unfolding of the underlying truth in 
God's children. These ethical exhortations, proceeding from the context of Jesus as the means of fellowship (1:6-2:2), culminate in the need

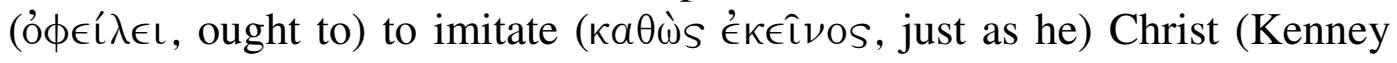
2000a:22; cf. also Von Wahlde 1990:217).

Verses 2:3-8 discuss the theme, verse 9 prepares for the climax in verse 10, while in verse 11 the climax is emphasized with an antithesis.

The passage contains three parallelisms: (1) recognition of our knowledge

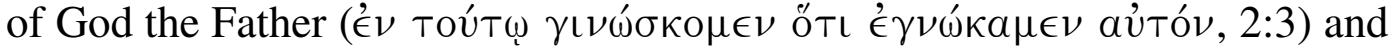

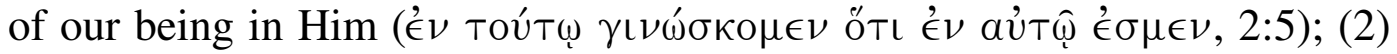

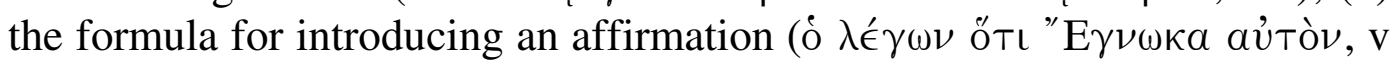

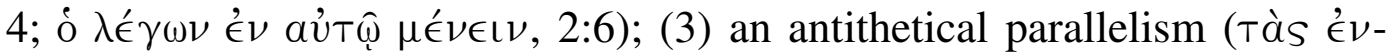

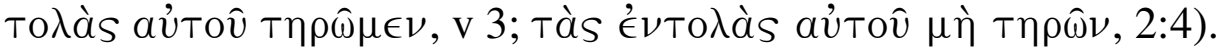

The verb $\pi \epsilon \rho \iota \pi a \tau \epsilon \hat{\imath} \nu$ occurs five times in 1 John: 1:6, 7; 2:6bis, 11. In 1:6, 7 it connects fellowship with walking in the light/darkness. In 2:11 it connects hatred with darkness and in 2:6 it connects fellowship

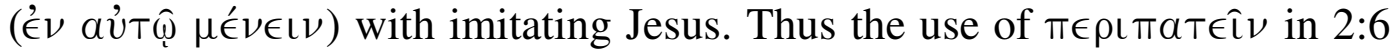

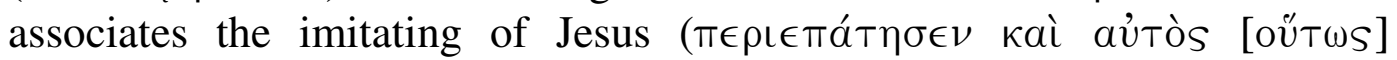

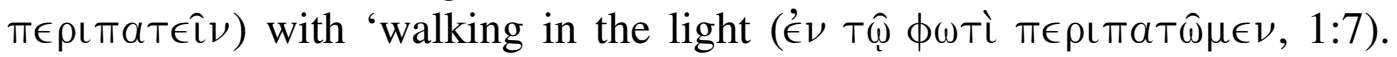
The infinitive ( $\pi \epsilon \rho \iota \pi \alpha \tau \epsilon \hat{\imath} \nu$ ) suggests a present, repeated action.

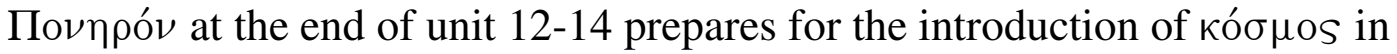
the first verse of sub-section 15-17. At the end of unit 15-17, eis tòv

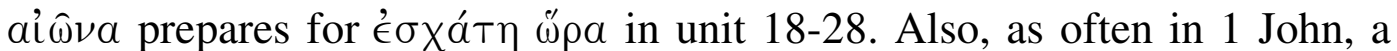
section of parenesis follows a series of dogmatic statements. The Elder's practical concern for his church members is never far from his theological teaching, given on their behalf. Indeed, doctrine and ethics belong closely together throughout these verses, since the author's explanation of true spirituality has a constantly practical thrust.

This sub-section is divided into two parallel clusters, which both aim semantically at the same goal. 'The purpose of this parallel recapitulation scheme is to accentuate' (Du Rand 1981:8).

'If anyone loves the world, the love of the Father is not in him ...'

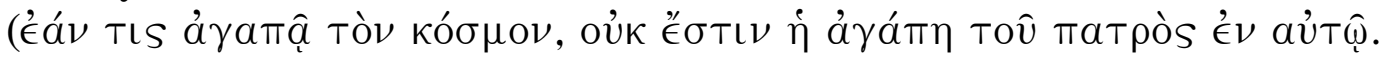
Elsewhere in the epistle $(1: 6-10 ; 2: 3,5,19,22 ; 3: 17 ; 4: 12,15,20)$ the conditional clause, as in this verse, also indicates an exterior criterion from which it is possible to conclude to an existing interior state. The behavior of one who loves the world is a sign that the love of the Father is not within him.

Verses $2: 5 ; 4: 12 ; 3: 17$ are parallel to $2: 15$ in the sense that they treat the indwelling presence of the love of God as correlative to a condition. Verses 2:5 and 4:12 describe ideal Christian conduct, while the remaining two refer to serious failures. 


\begin{tabular}{|c|c|c|}
\hline $2: 5$ & 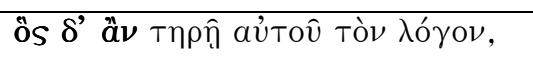 & 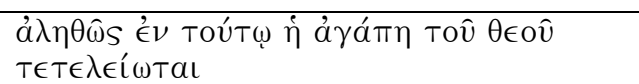 \\
\hline $4: 12$ & 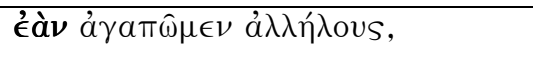 & 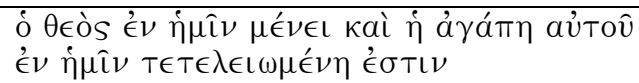 \\
\hline $3: 17$ & 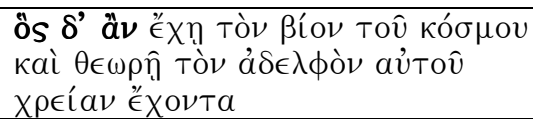 & 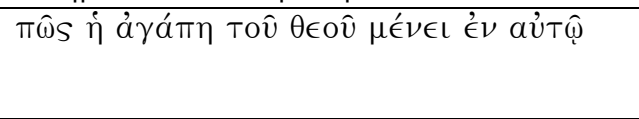 \\
\hline $2: 15$ & 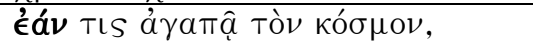 & 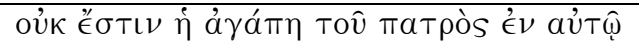 \\
\hline
\end{tabular}

From these parallel texts it is clear that loving the world is contrary to keeping God's word, to sharing, to loving one another. Love for the world then implies: the refusal to accept God's revelation, selfishness and hatred towards the brethren.

God's will can be summed up in the twofold command: 'believe in the name of his Son Jesus Christ and love one another (3:23). Faith and love are the realization of God's design in us and through these gifts we are filled with his love (2:15) and brought to share in his own life.

The high frequency of personal pronouns and verbs in the second person

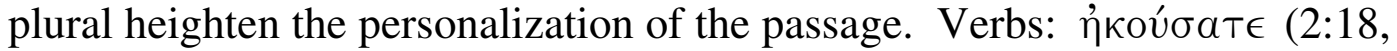

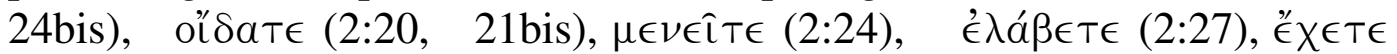

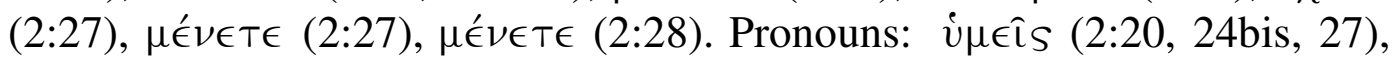

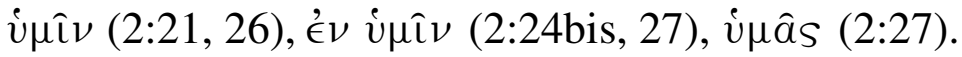

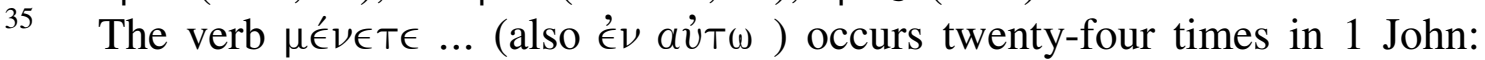
2:6, 14, 17, 19, 24ter, 27bis, 28; 3:6, 9, 14, 15, 17, 24bis; 4:12, 13, 15, 16ter. In all these texts it has a theological meaning. Once it is explained with $\epsilon i s$ (2:17), and once with $\mu \in T a ́$ (2:19). In all the other instances it occurs with $\stackrel{\epsilon}{\nu}(\mathbf{2}: 6,10,14$, 24ter, 27bis, 28; 3:6, 9, 14, 15, 17, 24bis; 4:12,

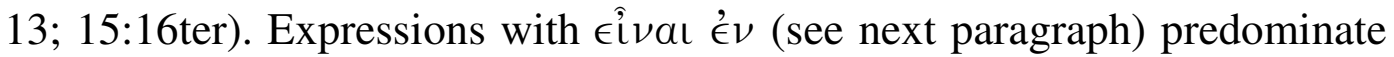

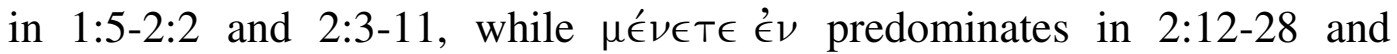
foreshadows, according to Malatesta (1978:231), the importance $\mu \in \operatorname{v\in } \in \nu$ will have in the rest of the epistle. This tendency definitely points to the Elder's desire to insist on perseverance.

$\epsilon \hat{\imath v a l}$ is the most frequent word in 1 John (99x). Fifty seven times it is used in an absolute sense (1:5ter, 8, 9; 2:2, 4, 7, 14, 18bis, 2ter, 25, 27bis, 29; 3:1, 2quater, 3, 4, 7bis, 10, 11, 12, 15, 20, 23; 4:3, 8, 10, 15, 16, 17, 20; 5:1, 3bis, 4, 5bis, 6ter, 7, 9bis, 11, 14, 16, 17bis). Eighteen times is it explained

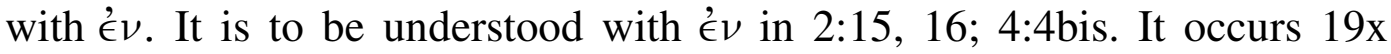
with '́ K (2:16bis, 19ter, 21; 3:8, 10, 12, 14; 4:1, 2, 3, 4, 5, 6bis, 7; 5:19), and

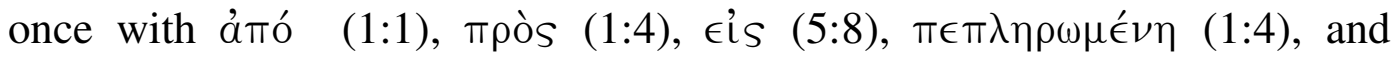

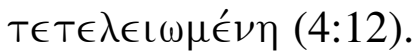

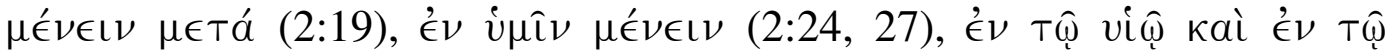

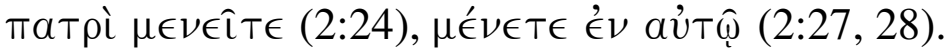

The use of $\mu \epsilon^{\prime} \nu \in \mathrm{L} \nu$ in $2: 17,19$ does not relate to the other texts $(2: 24,27)$ where it is used with the phrase $\epsilon^{\nu} \nu \dot{v} \mu \hat{\imath} \nu$. 
There are diverse interpretations of the meaning of the phrase Tò aưtov $\chi \rho \hat{\imath} \sigma \mu \alpha$. For most scholars it refers to the 'Spirit' (Haas, De Jonge and Swellengrebel 1972:65; Bruce 1975:71ff; Coetzee (1981:54); Krimmer 1989:64; Von Wahlde 1990:127; Schnackenburg 1992:67; Johnson 1993:57; Edwards 1996:54; Strecker 1996:76f; Painter 2002:198). See Malatesta (1978:204) for an opposite meaning. According to him 'we understand Tò $\chi \rho \hat{\imath} \sigma \mu \alpha$ to mean the word of God interiorized and assimilated by the believers under the action of the Holy Spirit.' Vorster (1975:94) interprets 'it as an event word and that it is possibly an illusion to baptism in which the Holy Spirit plays a significant role.'

Note that no one can have the Father without the Son. This unity between

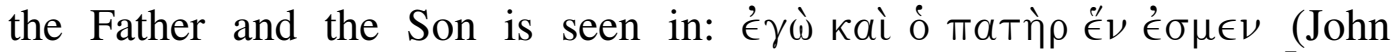

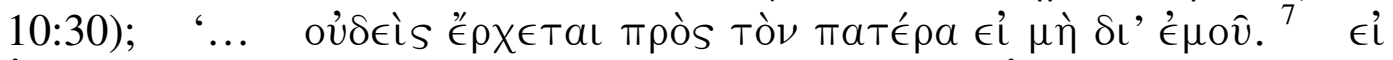

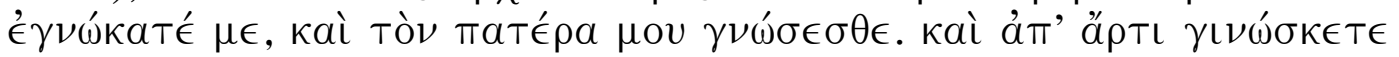

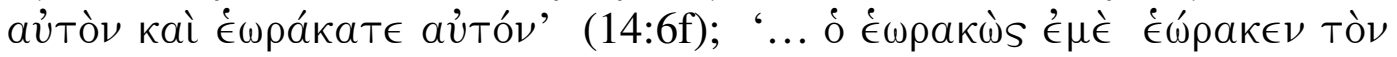
пате́pa ...' (14:9).

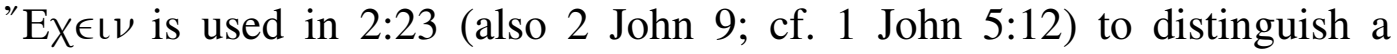
distinct relation to God. It makes the having of God as Father dependent on the confession of Christ as the Son, the Son of God and the Messiah in the flesh. Thus, having the Father includes having the Son. Only Christian believers can understand and accept that their fellowship with God is only constituted by way of fellowship with Christ. What it comprises to have the

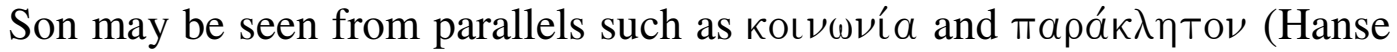
1978:823f).

41 Parallel expressions that connote various aspects of the revelation in Christ are: the word of God (2:14), the will of God (2:17), the anointing (2:20, $27 \mathrm{bis})$, what was heard from the beginning (2:24bis), and the promise $(2: 25)$.

According to 2:24 (also John 15:7; 8:31) is the abiding of Christ in his own inseparably linked with the abiding of his word in his followers. Therefore, 'he who says he abides in him ought to walk in the same way in which he walked' (2:6). According to Munzer (1978:226) demands and forms the indwelling Christ, or life through the word of Christ, a life conforming to his Spirit and nature, and wills and brings about sanctification.

A Christological accent is present throughout 2:18-28: 2:20: áто;

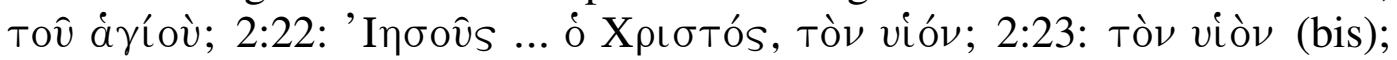

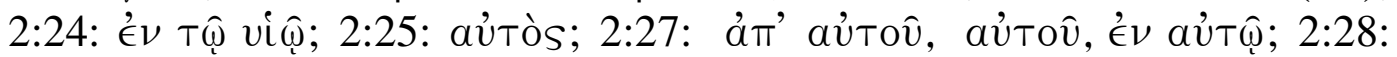

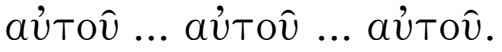

44 It occurs six times in 2:20-28; in 3:24 twice explicitly and once by implication; in 4:(12), 13-16 six times explicitly and twice by implication. In 3:24, where the gift of the Spirit is mentioned in close parallel to 4:13-6, the $\mu \epsilon \in \in \iota \nu$-motif also figures prominently. 
Throughout this unit a number of sources of revelation have been pronounced: the anointing possessed by the community it has from the Holy One (2:20) and has received from Him (2:27). What they have heard from the beginning, should abide in them (2:25). The anointing teaches them (2:27).

46

In 1 John 'abiding' is predominantly theocentric. In a number of texts the frequent and characteristic '́ $v$ aỦT $\hat{\varphi}$ (in him) allows for some ambiguity as to whether God or Jesus is intended $(2: 6,28 ; 3: 6,24 ; 4: 13)$, and in 2:24

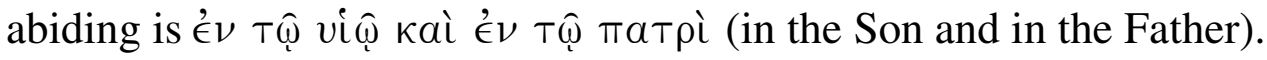
All the explicit references to the Spirit in 1 John is connected to the community $(2: 20,27 ; 3: 24 ; 4: 2,13)$ rather than to the individual. But implicitly, by implication is the Spirit definitely involved in the individual lives of believers (cf. $2: 23$; 3:17). In most cases (see previous footnote) the plural is used where the Elder uses $\mu \epsilon \in v \in L \nu$ and the singular where he uses ÉX $\in \mathrm{LV}(2: 23 ; 5: 12)$.

The verb 'to abide' ( $\mu$ '́ $\nu \in \iota \nu)$ must not be confused with 'becoming' a child of God. Through faith $(5: 1,13)$ and rebirth $(5: 1)$ one has become a child of God. To abide in Christ succeeds rebirth and relates to God's guidance and the experience of his presence and communion in the believer's life. 